\title{
RANGE PLANT COMMUNITIES AND CARRYING CAPACITY FOR THE UPPER FOOTHILLS SUBREGION
}
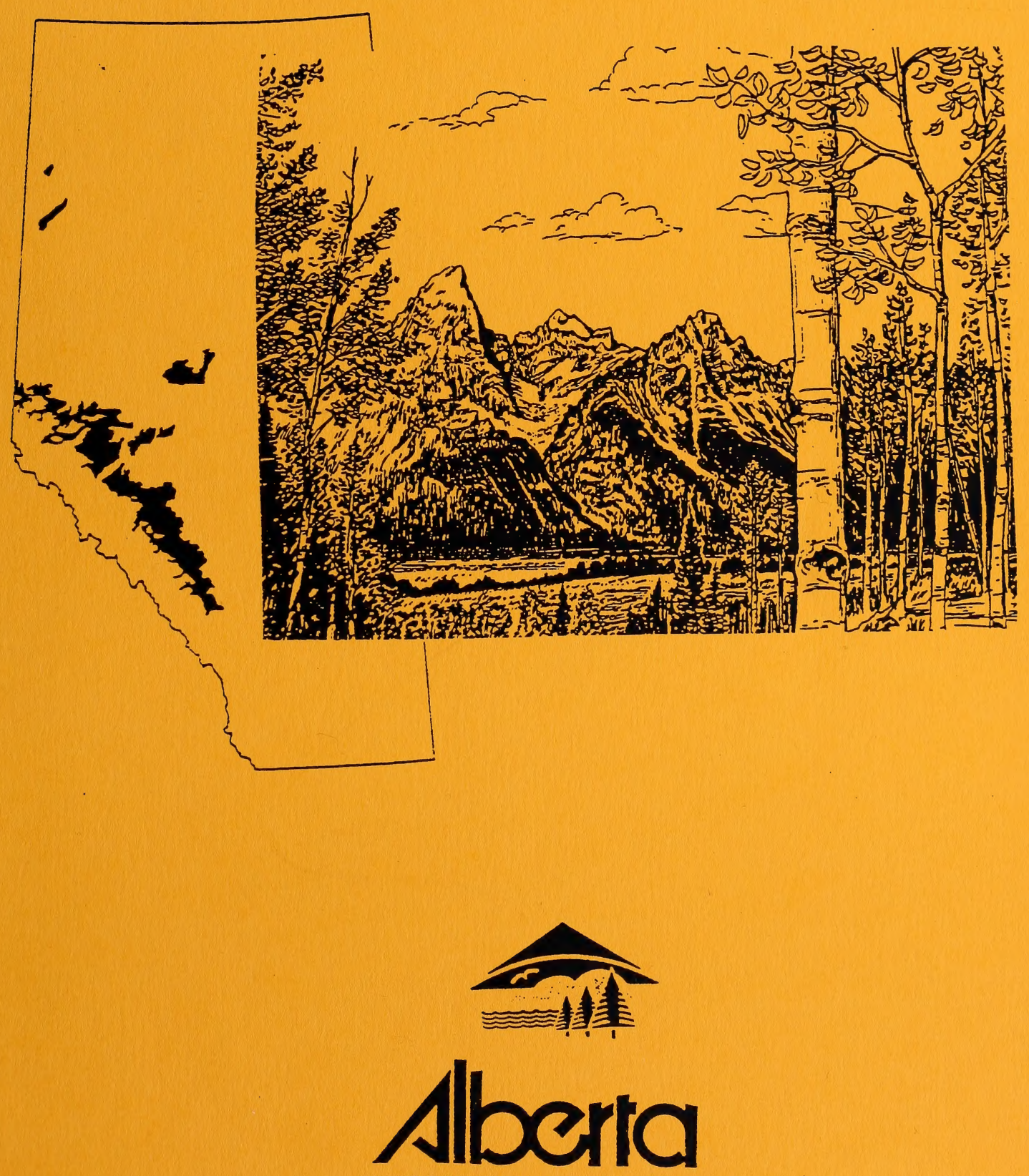



\title{
RANGE PLANT COMMUNITY TYPES AND CARRYING CAPACITY FOR THE UPPER FOOTHILLS SUBREGION
}

Second approximation

\author{
1997 \\ Prepared by \\ Michael G. Willoughby \\ and \\ Darrell Smith
}

Edmonton

Environmental Protection

1997

Lands and Forest Services 
Digitized by the Internet Archive in 2015

https://archive.org/details/rangeplantcommun00will 
Pub. no. T/356

ISBN: 0-7732-5110-3

For copies of this report contact:

Michael Willoughby

9920108 st, 9th Floor

Edmonton, Alta.

T5K2M4

(403) $422-4598$

E-mail: mwilloug@env.gov.ab.ca 

Introduction

Climate of Upper Foothills subregion

Methods

How to use guide

Results

Native grass and shrublands

Key to native grasslands

Key to native shrublands

A. Grasslands

UFA1. Water sedge meadows

UFA2. Sedge-Slender wheatgrass/Meadow rue

UFA3. Tufted hairgrass-Sedge

UFA4. Tufted hairgrass-Sedge-Slender wheatgrass

UFA5. Rough fescue-Tufted hairgrass

UFA6. Rough fescue-Hairy wildrye

UFA7. Rough fescue/Bearberry

UFA8. California oatgrass-Sedge

UFA9. Junegrass/Sage

UFA10. Early yellow locoweed-Bearberry/Slender wheatgrass

UFA11. Fireweed/Hairy wildrye(Forb meadow)

UFA12. Rough fescue-Bog sedge

UFA13. Alpine rough fescue

B. Shrublands

UFB1. Willow-Bog birch/Water sedge

UFB2. Willow/Slender wheatgrass-Sedge

UFB3. Willow/Tufted hairgrass

UFB4. Willow/Rough fescue

UFB5. Bog birch/Rough fescue/Bearberry 

UFB6. Willow/California oatgrass-Sedge 36

UFB7. Pussy willow shrubland 37

UFB8. Willow/Hairy wildrye-Sedge 38

UFB9. Bog birch/Sedge-Marsh reedgrass $\quad 39$

UFB10. Willow-Bog birch/Sedge 40

UFB11. Willow-Bog birch 41

C. Shrublands and Grasslands modified by grazing 42

UFC1. Slender wheatgrass-Sedge/Low forbs 45

UFC2. Rocky Mtn. fescue/Graceful cinquefoil 46

UFC3. Kentucky bluegrass/Dandelion $\quad 47$

UFC4. Kentucky bluegrass-Sedge/Dandelion $\quad 48$

UFC5. Tufted hairgrass-Kentucky bluegrass $\quad 49$

UFC6. Sedge-Tufted hairgrass $\quad 50$

UFC7. Creeping red fescue/Clover 51

D. Deciduous community types $\quad 52$

UFD1. Aspen-Lodgepole pine/Purple oatgrass 55

UFD2. Balsam poplar-White spruce/Willow/Yellow Mtn. avens 56

UFD3. Aspen/Rose/Hairy wildrye $\quad 57$

UFD4. Aspen-White spruce/Buffaloberry/Hairy wildrye 58

$\begin{array}{ll}\text { E. Conifer community types } & 59\end{array}$

UFE1. Lodgepole pine/Bog cranberry 62

UFE2. Lodgepole pine-White spruce/Bunchberry 63

UFE3. Lodgepole pine/Willow/Moss 64

UFE4. Lodgepole pine/Marsh reedgrass 65

UFE5. Black spruce/Willow 66

UFE6. White spruce/Horsetail/Moss 67

UFE7. White spruce/Willow 68

UFE8. White spruce/Bearberry 69

UFE9. White spruce/Juniper $\quad 70$

$\begin{array}{ll}\text { F. Cutblock community types } & 71\end{array}$

UFF1. Juniper/Hairy wildrye $\quad 72$

UFF2. Rose/Hairy wildrye $\quad 73$

$\begin{array}{ll}\text { Literature cited } & 74\end{array}$ 

Appendix 1. Species vegetation species lists for each community type (See Volume II)

\section{List of Figures}

Figure 1. Overview of native shrub and grassland complex in the Upper

Foothills subregion

Figure 2. Typical native shrub and grassland transition zone in the Upper

Foothills subregion

Figure 3. Layout of plant community types for native grass and shrublands in the landscape of the Upper Foothills subregion

Figure 4. Heavily grazed Kentucky bluegrass/Dandelion community type

Figure 5. Aspen/Rose/Hairy wildrye community type on south facing slopes in the Upper Foothills subregion

Figure 6. The Lodgepole pine-White spruce/Bunchberry community is the dominant conifer community type in the Upper Foothills subregion

Figure 7. The Juniper/Hairy wildrye community type results from the harvesting of a White spruce/Juniper community

\section{List of Tables}

Table 1. Ecosites and ecosite phases of the Upper Foothills subregion

Table 2. Native grass and shrublands of the Upper Foothills subregion

Table 3. Shrublands and grasslands modified by heavy grazing in the

Upper Foothills subregion

Table 4. Deciduous community types within the Upper Foothills subregion

Table 5. Conifer community types of the Upper Foothills subregion

\section{List of Maps}

Map 1. Location of Upper Foothills subregion in Alberta 



\begin{abstract}
The Upper Foothills subregion is found elevationally belwo the Subalpine and above the Lower Foothills subregions. It is dominated by closed canopied lodgepole pine forests. In the valley bottoms the shrub and grassland community types are a classic example of multiple use land, providing summer range for livestock, prime habitat for many species of wildlife, productive watersheds and recreational areas. Despite the importance of these vegetation types for livestock grazing, there is little information available on how grazing affects their production. There is little information on forage productivity, carrying capacity and the associated community types with grazing. The lack of information makes it very difficult to development management prescriptions for multiple use. As a result a "Carrying capacity guides" was developed for the Upper Foothills subregion to provide a framework that would easily group the vegetative community types. It is hoped this classification system can be used by field staff to assess carrying capacity and evaluate range condition on lands within the region.

This guide represents the analysis of 210 plots described in the Upper Foothills subregion, near Grande Cache (Willmore Wilderness Park) and west of Rocky Mtn. House during the summers of 1990-1996. The 210 plots represent 46 community types. These types are split into:
\end{abstract}
A. Native grasslands
13 community types
B. Native shrublands
11 community types
C. Grazing modified types
7 community types
D. Deciduous types
4 community types
E. Conifer types
9 community types
F. Cutblocks
2 community types

The dominant plant species, canopy cover, environmental conditions, response to grazing, forage production and carrying capacity are outlined for each type. 



\section{Introduction}

The province of Alberta is covered by a broad spectrum of vegetation regions from prairie in the South, to alpine vegetation in the mountains and dense forests in the Central and Northern parts of the province. These broad vegetation regions have been classified into 6 natural regions and 20 subregions for the province (Dept. of Environmental Protection 1994). Each of the regions consists of groups of plant communities which are influenced by environmental conditions and human impacts. Intensive management of these regions requires the ability to recoqnize the vegetative communities that have similar productivities and respond to disturbance in the same way. The increase in use of Alberta's northern forests has recently stimulated efforts to develop detailed classification systems. Some of these classification systems include "Field guide to Forest ecosystems of West Central Alberta" (Corns and Annas 1986) and "Field Guide to Ecosites of West-Central Alberta" (Beckingham et al. 1996).

The vegetative communities in the province of Alberta are highly regarded by most resource managers for their ability to provide a wide variety of benefits. They are a classic example of multiple use land, providing summer range for livestock, prime habitat for many species of wildlife, productive watersheds and recreational areas. Despite the importance of these vegetation types for livestock grazing, there is little information available on how grazing affects their production. Specifically, there is little data on the levels of utilization which are detrimental to communities growth. There is also no data on forage productivity, carrying capacity and associated community types with grazing. Traditionally, these community types have been rated at $5 \mathrm{ac} / \mathrm{AUM}$ or $60 \mathrm{ac} / \mathrm{head} / \mathrm{year}$, but recent work has shown that productivity can vary significantly depending upon the ecological conditions of the site.

The purpose of this guide was to develop a framework that would easily group the vegetative community types in the Upper Foothills subregion of the province. The ultimate goal is a classification system that can be used by the field staff to assess carrying capacity and evaluate range condition on lands within the region. This guide supplements the work done by Beckingham et al. (1996) on the forested community types in the Upper foothills subregion. His guide describes 65 community types on 13 ecosites. Beckingham's guide is a good description of the forested community types found within the subregion, but it does not include forage production values and carrying capacities. It also only provides a brief description of the native shrubland and grassland communities which are extensively utilized by livestock and wildlife in this subregion.

\section{Climate of Upper Foothills subregion}

This subregion is found elevationally below the subalpine and above the Lower Foothills subregions. It ranges in elevation from $1200-1500 \mathrm{~m}$ at lower latitudes and from $1000-1250 \mathrm{~m}$ at higher latitudes. It is dominated by closed canopy lodgepole pine forests with the potential climax species on reference sites being white spruce and black spruce. This subregion can be distinguished from the Subalpine subregion by the lack of engelmann spruce and from the Lower Foothills by the lack of aspen. 

This subregion has a boreal climate which is modified by the Rocky Mountains. The average annual precipitation is $538 \mathrm{~mm}$ with over half the precipitation recieved in the summer months $(340 \mathrm{~mm})$. The temperature averages $11.5^{\circ} \mathrm{C}$ in the summer and $-6.0^{\circ} \mathrm{C}$ in the winter. These temperatures are milder and not nearly as extreme as the other subregions within the Boreal forest and Foothills natural regions.

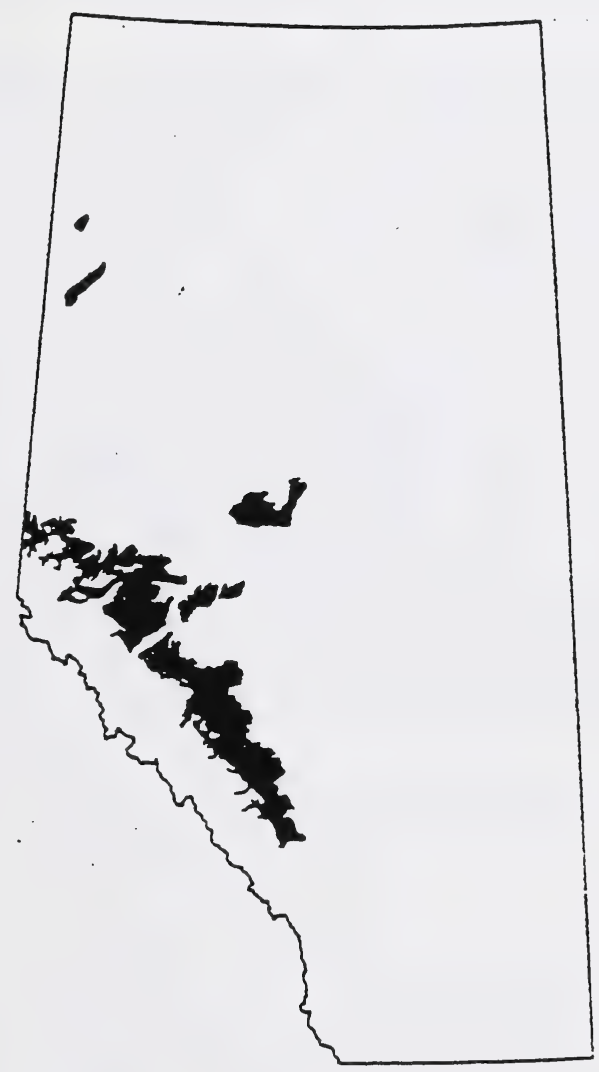

Map 1. Location of Upper Foothills subregion in Alberta 



\section{Methods}

A community type approach (Mueggler 1988) to classification was chosen in preference to the habitat type approach (Daubenmire 1952) or ecosystem association approach (Corns and Annas 1986) because of the lack of understanding of the successional sequences of the communities. Community types are aggregates of similar plant communities based upon existing floristics regardless of successional status (Mueggler 1988). Community types are what is actually seen in the field. After defining the community types, they then can be linked to the ecosystem associations developed by Corns and Annas (1986) and Beckingham (1994). In the mean time community types can be used as the basis for mapping and range management planning.

Initially, grazing dispositions were inventoried by forest region in order to develop management plans following the procedure outlined in the Rangeland Resource Information System (1991). Individual plots were initially classified within a forest region using cluster analysis (SAS) and ordination (DECORANA, Gauch 1982). These types were described in individual carrying capacity guides for each forest. This led to differences in classification of the same types between forests, particularly for deciduous forest types. In an effort to standardize the community name and gain some understanding of each community types ecology, all plots sampled in each forest were reclassified. As the study progressed it became quite evident that there were differences in the productivity of the communities between ecoregions. As a result, it was decided to develop the classification within the ecoregion framework (Strong and Leggat 1992). An ecoregion is a geographical area that has broad vegetation zones combined with climatic data (Strong and Anderson 1980). As a result, the vegetation within each ecoregion is strongly influenced by the climatic conditions. Recently, the department has adapted the Natural and Subregions of Alberta classification system. This system incorporates the Natural regions and subregions classification used by Parks with the Ecoregions of Alberta classification used by Forestry, Lands and Wildlife. The Upper Foothills subregion and Upper Boreal Cordilleran ecoregion share the same boundary.

Sampling for this guide occurred within the Upper Foothills subregion. This guide outlines the classification of 210 plots described during the summers of 1990-1996 in the Southern and Northern East Slope Forest regions.

A plot consisted of a $10 \times 10 \mathrm{~m}$ macroplot and ten randomly selected $1 \times 1 \mathrm{~m}$ microplots to record the canopy cover of shrubs and ten nested $20 \times 50 \mathrm{~cm}$ microplots to record the canopy cover of forbs and grass. The inventory followed the Range Survey Manual (1992) and uses the MF5 form. At each macroplot a 50x100 cm was clipped and separated into trees, shrubs, forbs and graminoids, oven dried and weighed. The recommended stocking rate is based on 25 percent of the total production for forested types and $50 \%$ total production for grass and shrubland types and the fact that one animal requires $455 \mathrm{~kg}$ of dry weight material for one month of grazing. 



\section{How to use the guide}

First decide what category the community type is in. If it is in the Native grass and shrub category it will not have tree cover and be found on steep south facing slopes or moist lowland areas adjacent to streams and rivers. The predominant species will be native grasses, willow and bog birch. The Grazing modified community types will resemble the native shrub and grassland community types, but will show signs of extensive grazing pressure. These community types will be dominated by grazing resistant species Kentucky bluegrass, clover and dandelion. A couple of moderately grazed community types with a predominant native species cover are also found in this category.

The Deciduous category will be plant communities dominated by deciduous tree species aspen and balsam poplar and the Conifer category will be plant communities dominated by white spruce, lodgepole pine or black spruce tree species.

In order to understand how the community types in this guide are related to the ecosites and ecosite phases outlined in "Ecosites of West-Central Alberta" (Beckingham et al. 1996), the community types in this guide are arranged by ecosite and ecosite phase (Table 1). Ecosites are defined as ecological units that develop under similar environmental influences (climate, moisture and nutrient regime). An ecosite phase is a subdivision of the ecosite based on the dominant species in the canopy. Table 1 is a reproduction of Figure 14 in the Ecosites of West-Central Alberta guide with the community types in this guide highlighted. For the most part the ecosites and ecosite phases are the same, particularly for the forested community types, but a number of new ecosites and ecosite phases had to be created for the grass and shrubland community types (Table 1). These included (ee)(mesic/medium) grass/shrubland, (ff)(mesic/rich) fescue grassland ecosites and the (b3) bearberry grassland, (c5)yellow mtn. avens, (ee1) grassland, (ee2) shrubland, (ff1) grassland, (ff2) shrubland and (g3) grass meadow ecosite phases. These new ecosites and ecosite phases will likely never become forested because of deep snow accumulations and/or cold air drainage. The "Grazing succession" category (Table 1) outlines the successional sequence the community type will undergo with increased grazing pressure.

\section{Results}

The analysis of the 210 plots distinguished 46 community types. These types were split into 5 categories:
A.) Native grasslands
(13 types)
B.) Native shrublands
(11 types)
C.) Grazing modified types
(7 types)
D.) Deciduous types
(4 types)
E.) Conifer types
(9 types)
F.) Cutblock types
(2 types)

The dominant plant species, canopy cover, environmental conditions, forage production and carrying capacity are outlined for each community type. 



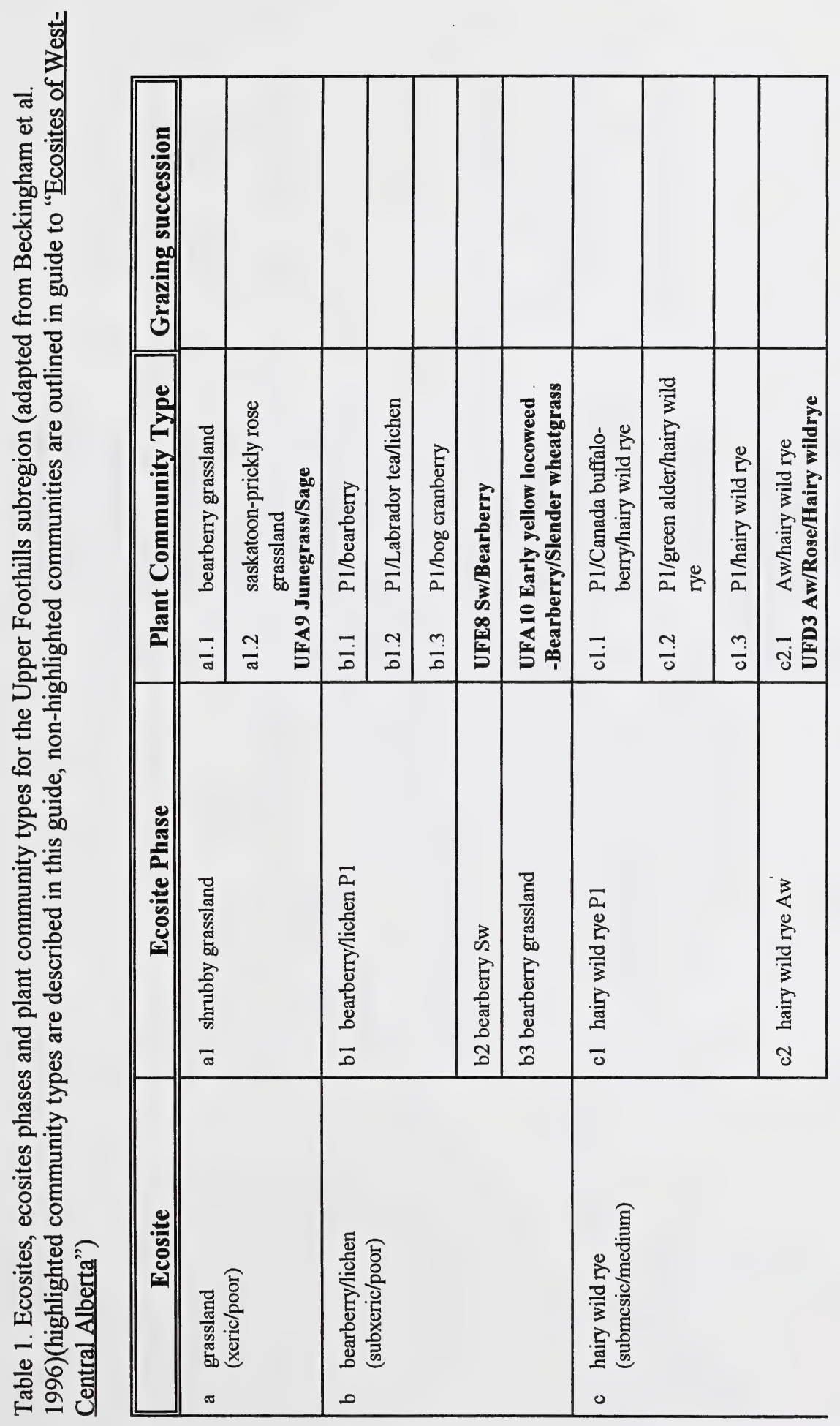





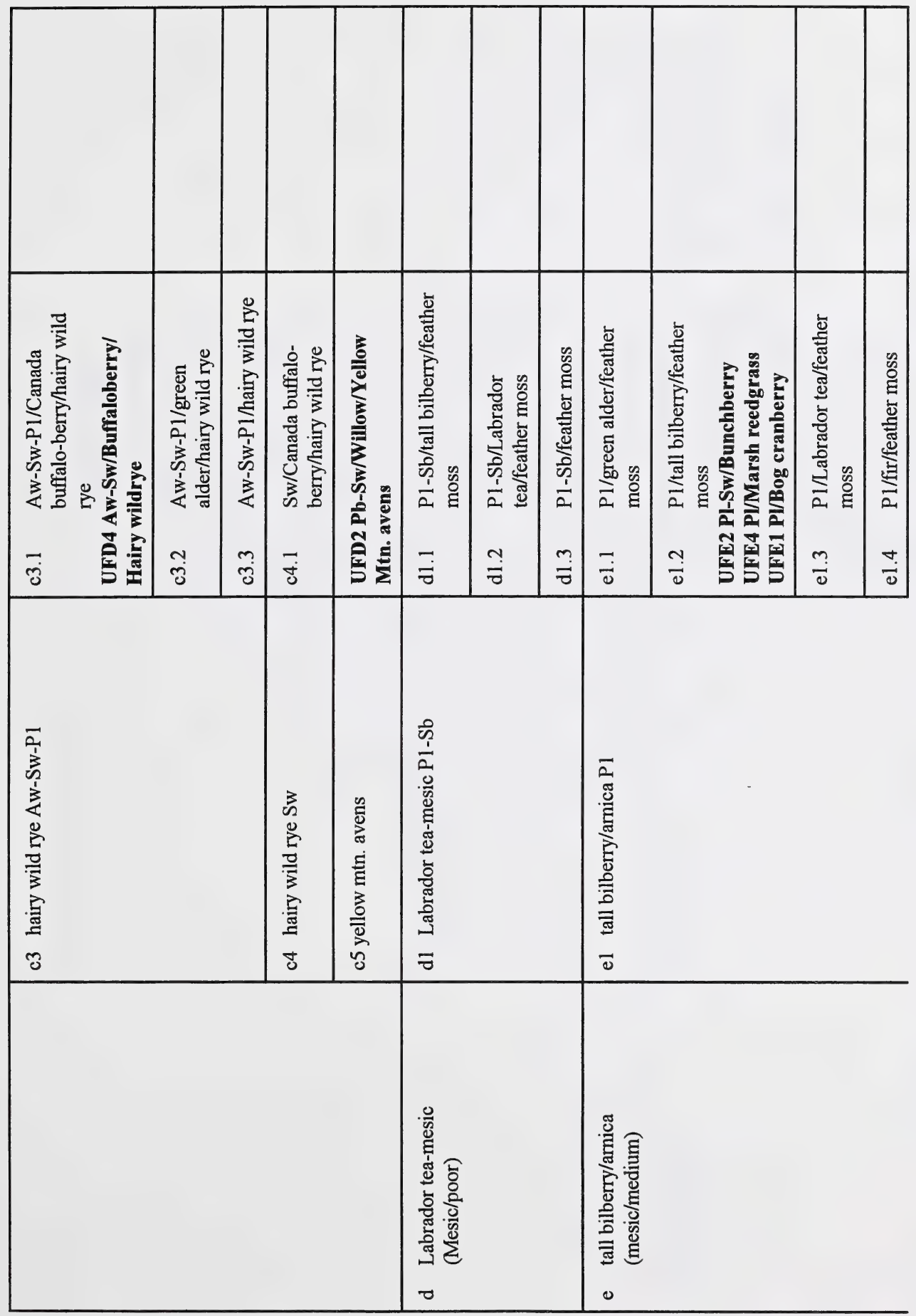





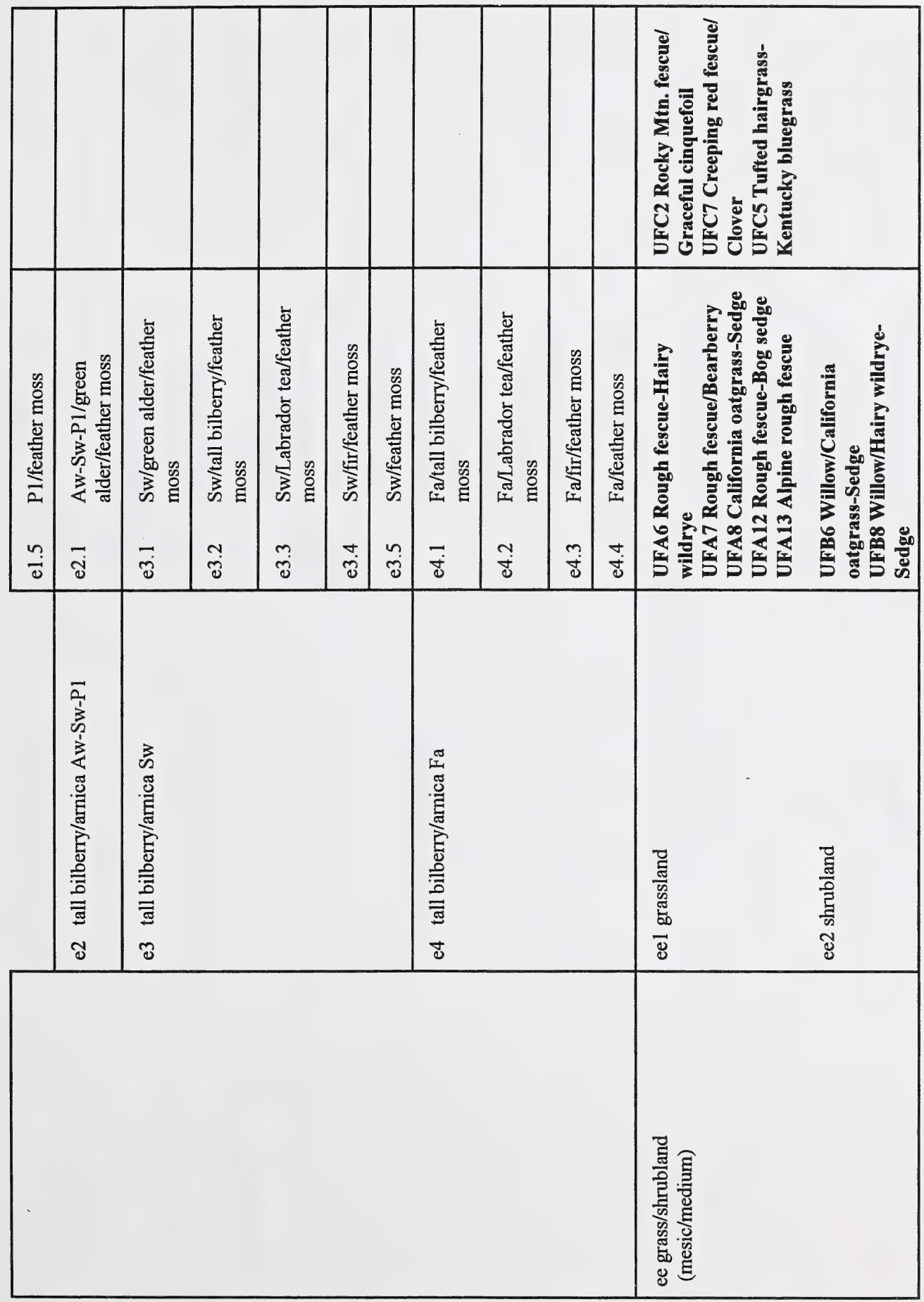




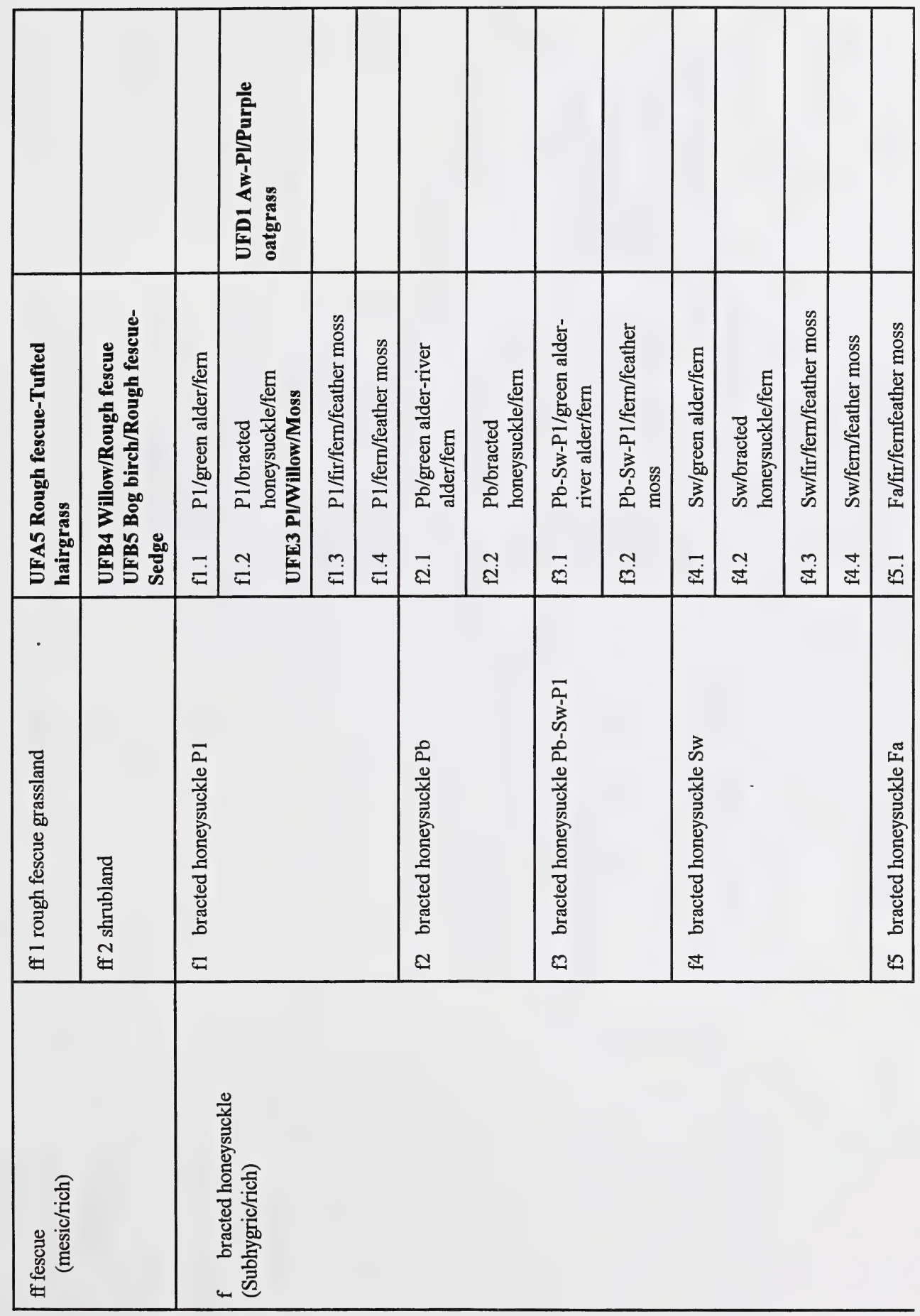





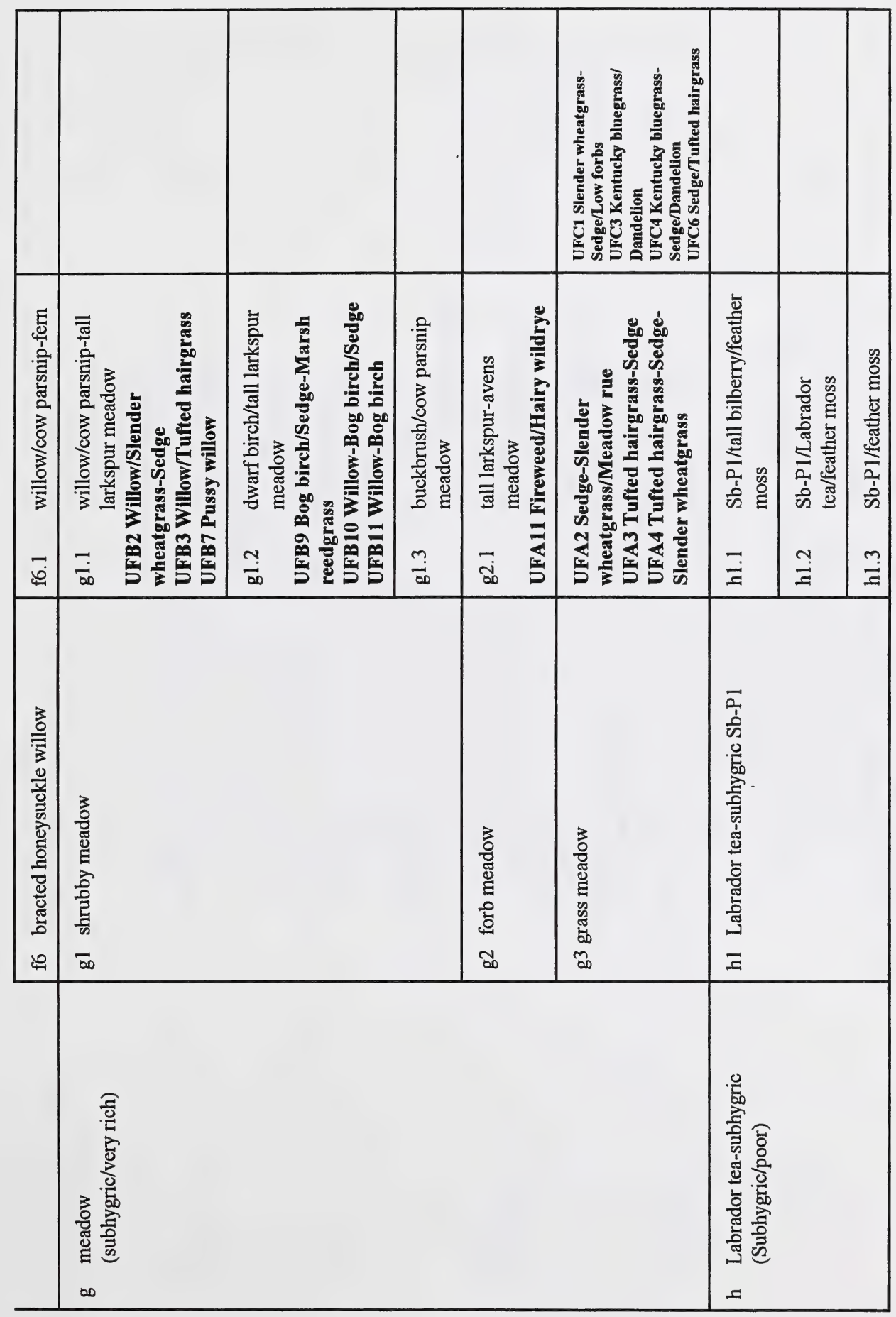





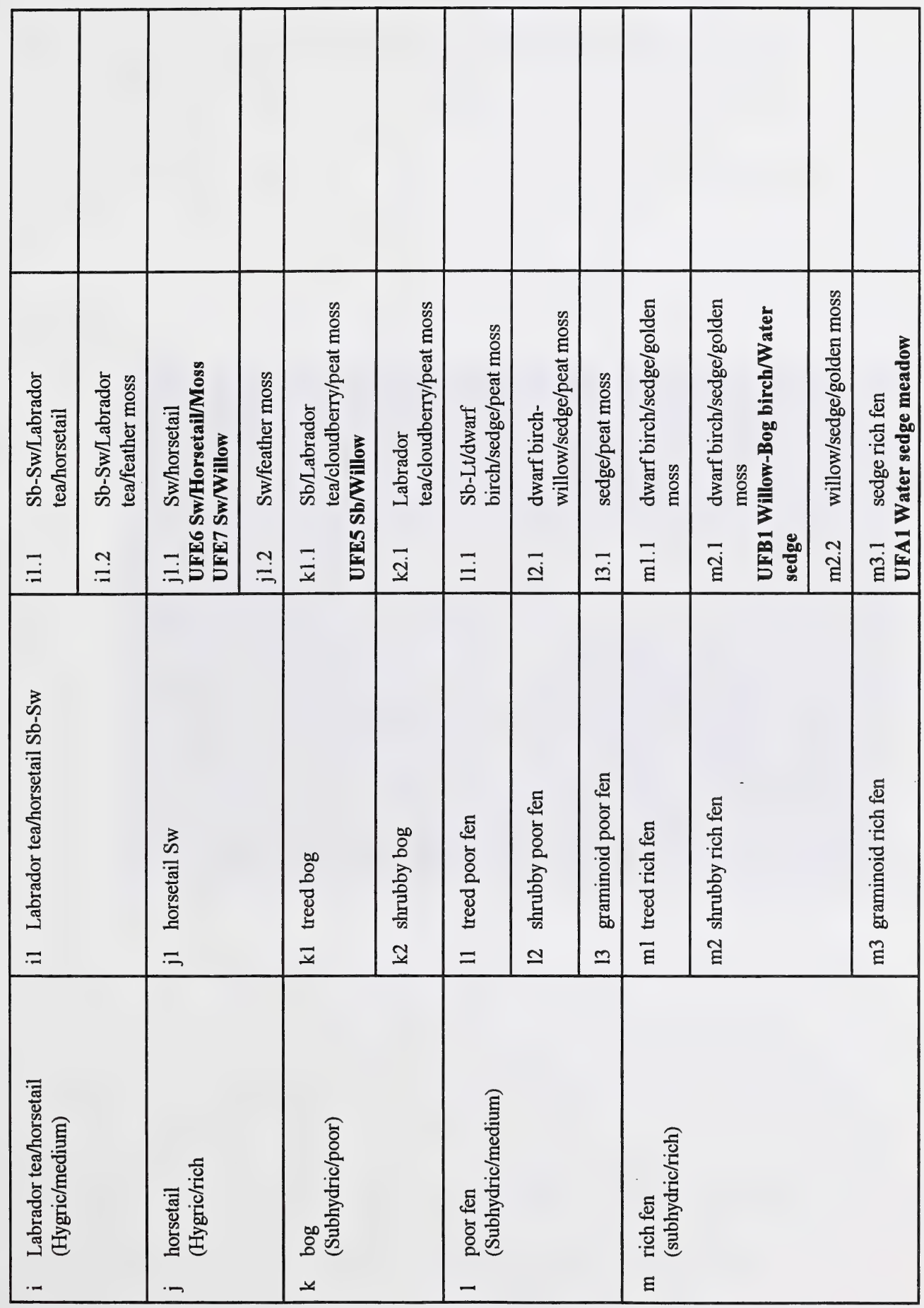





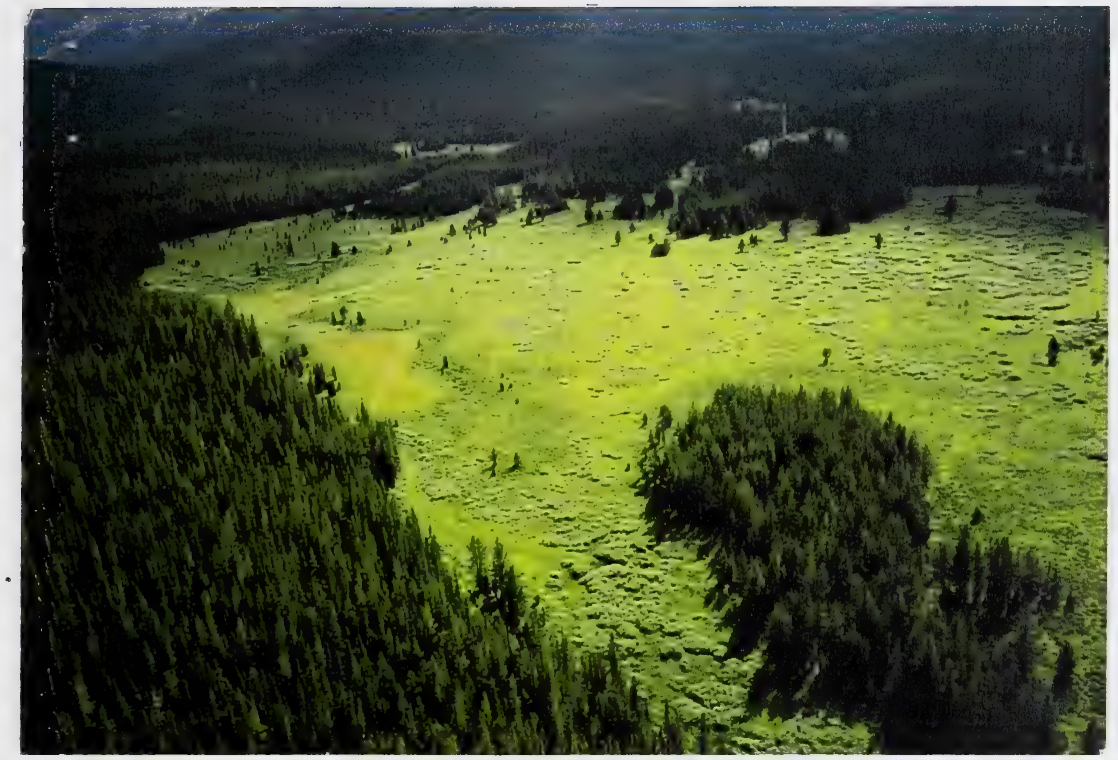

Figure 1. Overview of native shrub and grassland complex in the Upper Foothills subregion 



\section{Native grass and shrublands}

The native grass and shrubland community types (Table 2 ) are found in the valley bottoms adjacent to streams and rivers throughout the Upper Foothills subregion. Deep snow accumulations and/or cold air drainage prevent trees from growing in these valley bottoms (Daubenmire 1978). These grass and shrublands, historically burned frequently further preventing tree encroachment.

The sequence of these community types along a moisture gradient from wet (Sedge meadows) to dry (Junegrass/ Sage slopes) is outlined in Figure 3. The change in species composition from the wet sedge meadows to rough fescue and California oatgrass meadows may occur over a 3 foot elevational gradient.

The maintenance of these grassland community types is extremely fire dependent. The lack of fire quickly allows bog birch and willow to expand shading the modal grassland community types. Prolonged shading causes the understory composition to shift from a tufted hairgrass-rough fescue dominated understory to a slender wheatgrass-sedge dominated understory (Figure 3). Under a heavy shrub cover (Pussy willow shrubland and Willow-Bog birch community types) there is little forb or grass cover. Increased shrub cover also causes a decline in forage productivity and reduces the accessiblility for livestock.

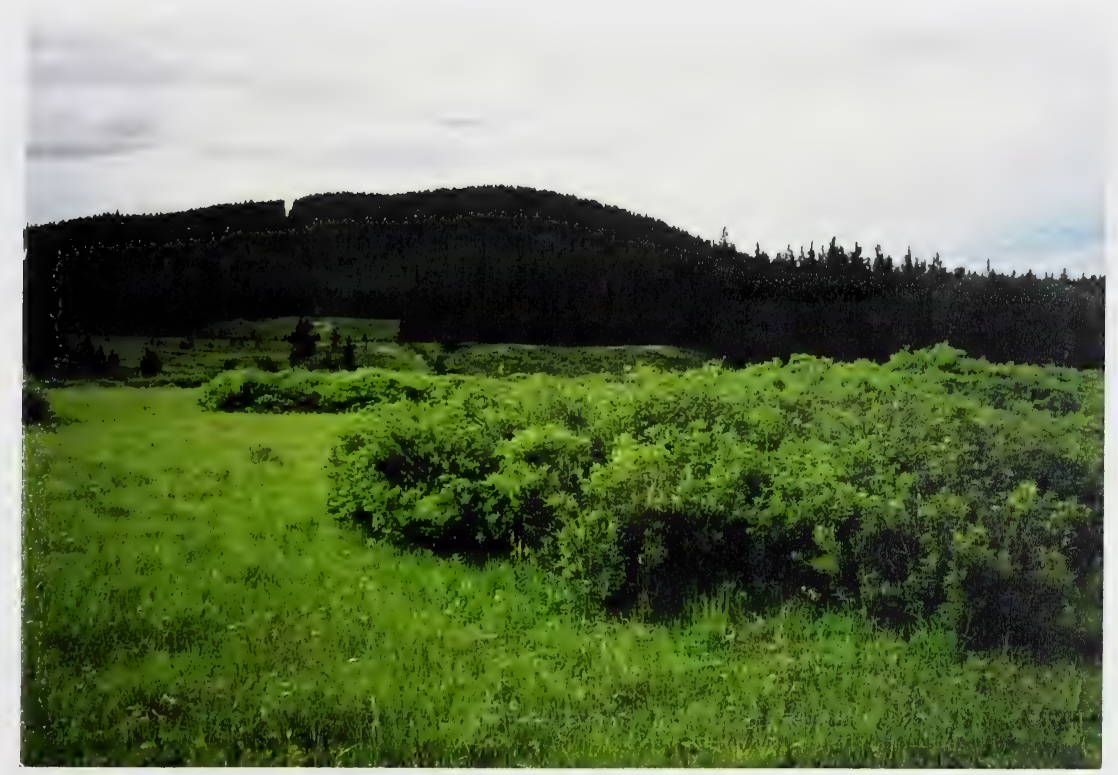

Figure 2. Typical native shrub and grassland transition zone in Upper Foothills subregion 


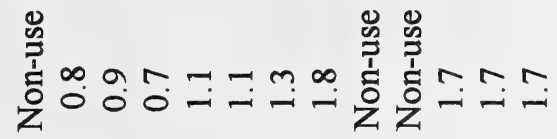

总て-

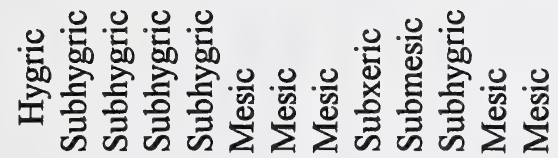

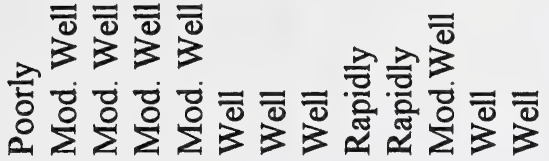

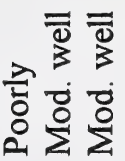

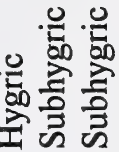

ฐิ

की

ㄱㅇㅇㅇ $\infty=$

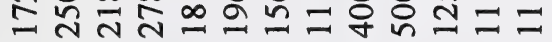

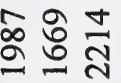

क을

产 䒿

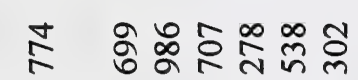

, ,

그, $\bar{n}$

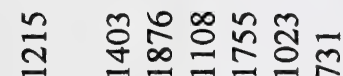

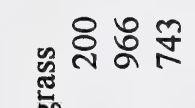

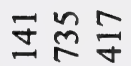

$\stackrel{\infty}{n} \mathfrak{n}$

衣

总

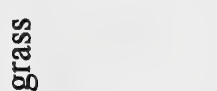

冚

焉

Z

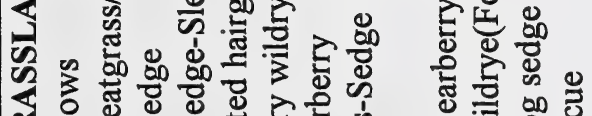

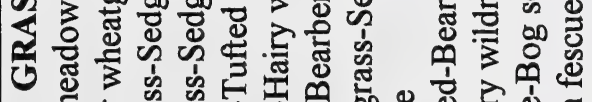
¿

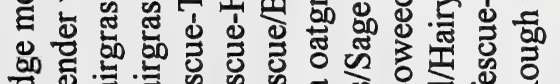

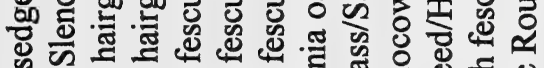

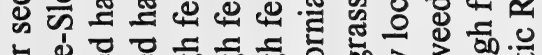

$\sum_{7}^{\infty}$

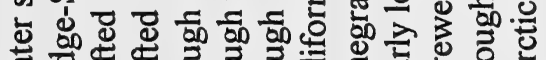

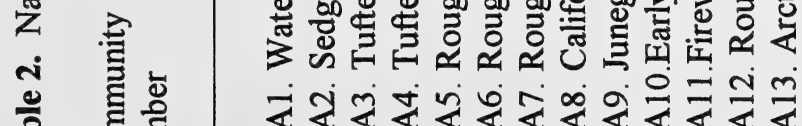

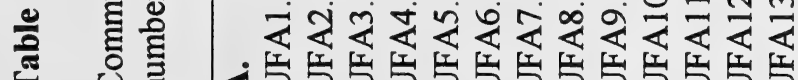

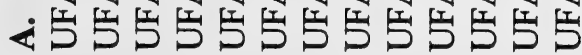

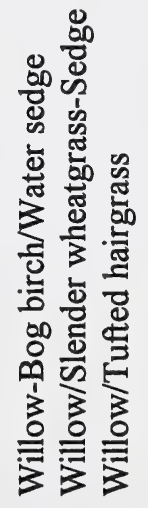


1

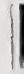

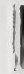


|

苑

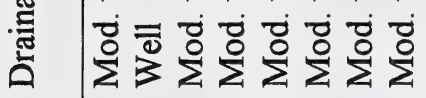

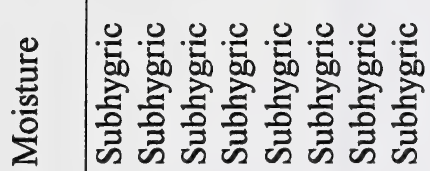

츙

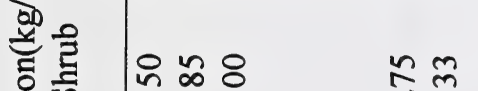

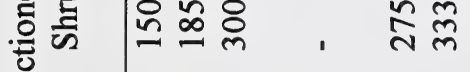

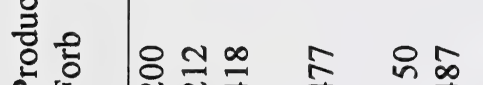

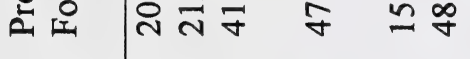

胥

范 


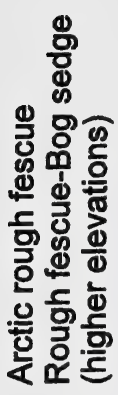

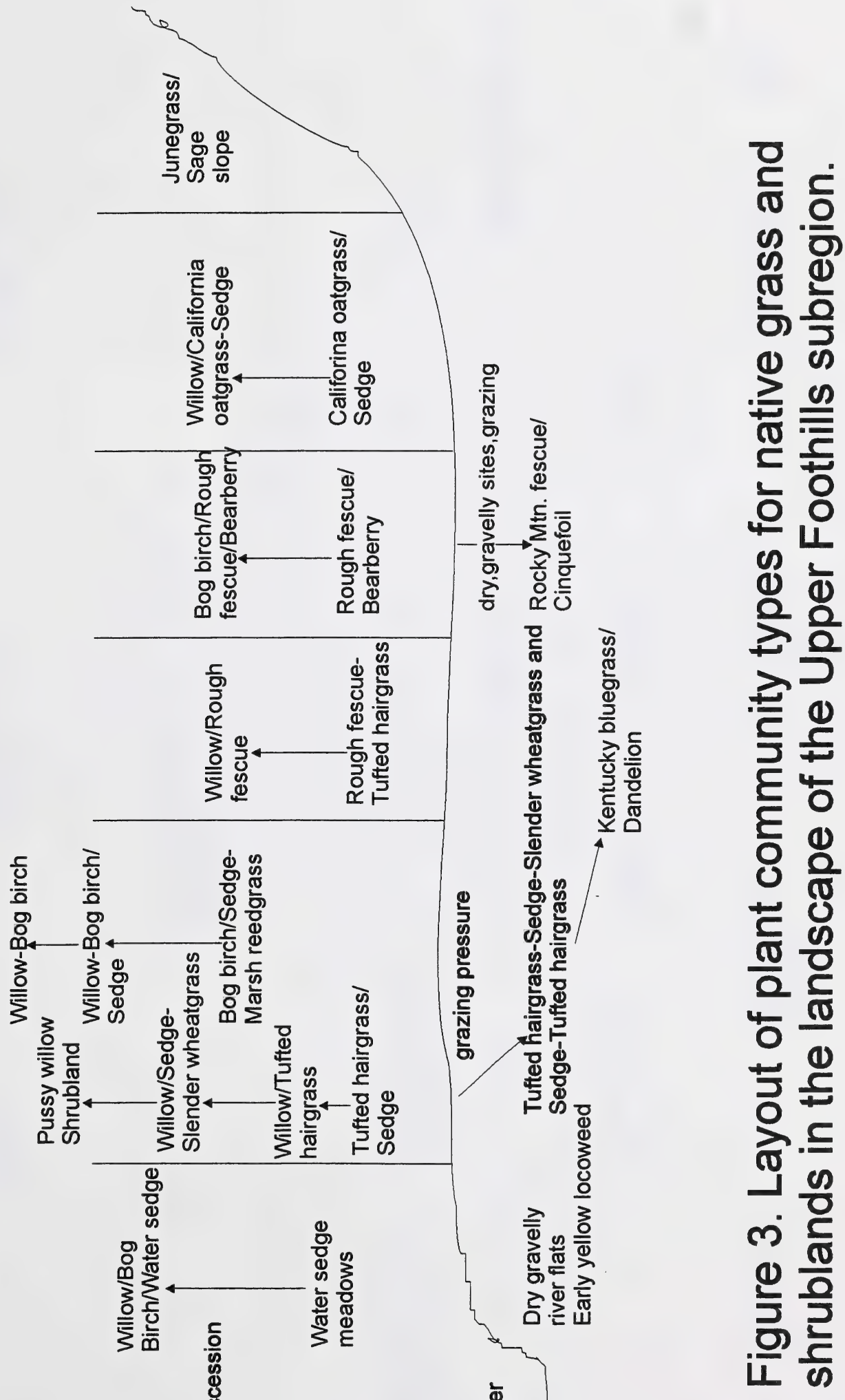



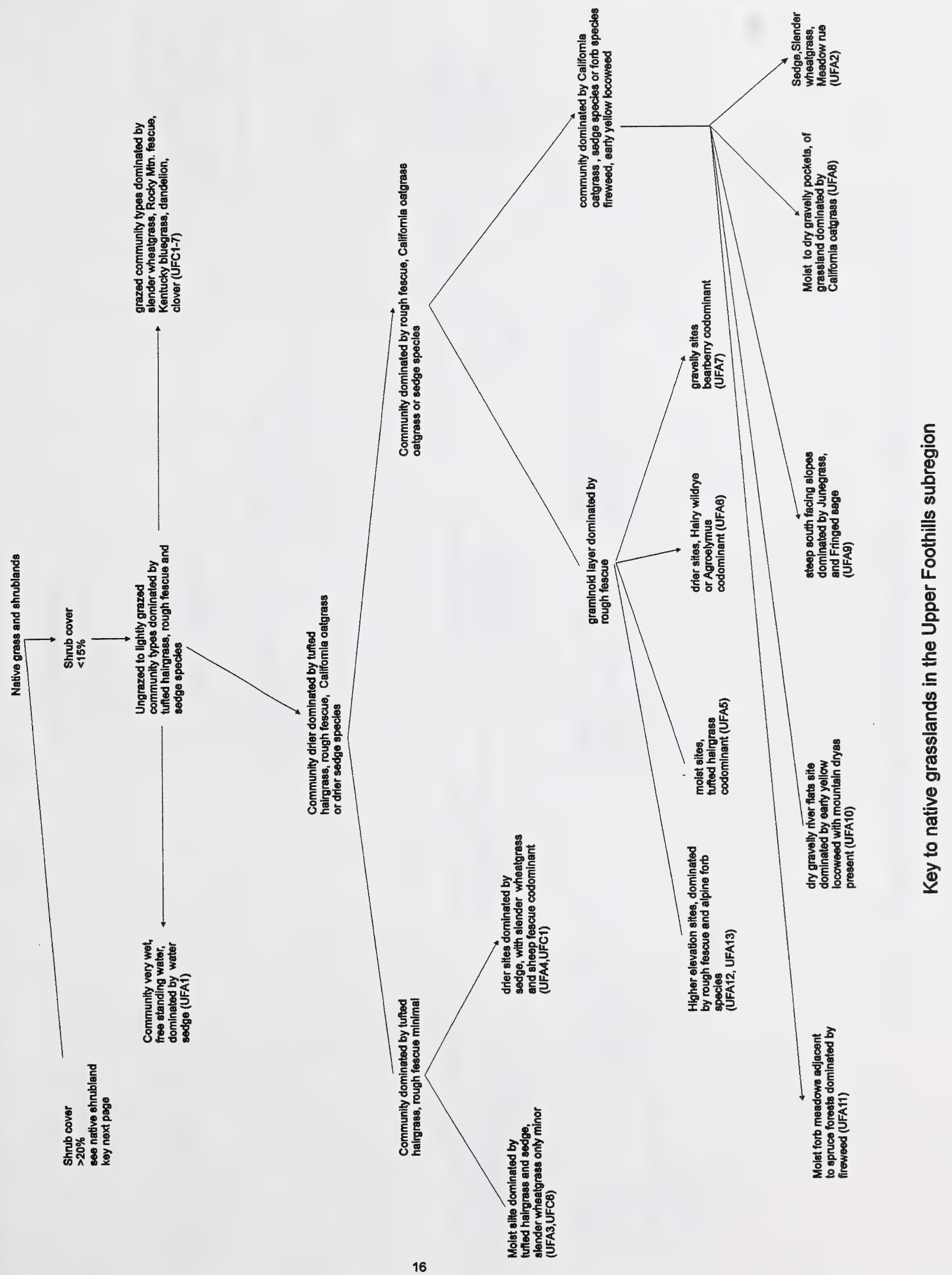


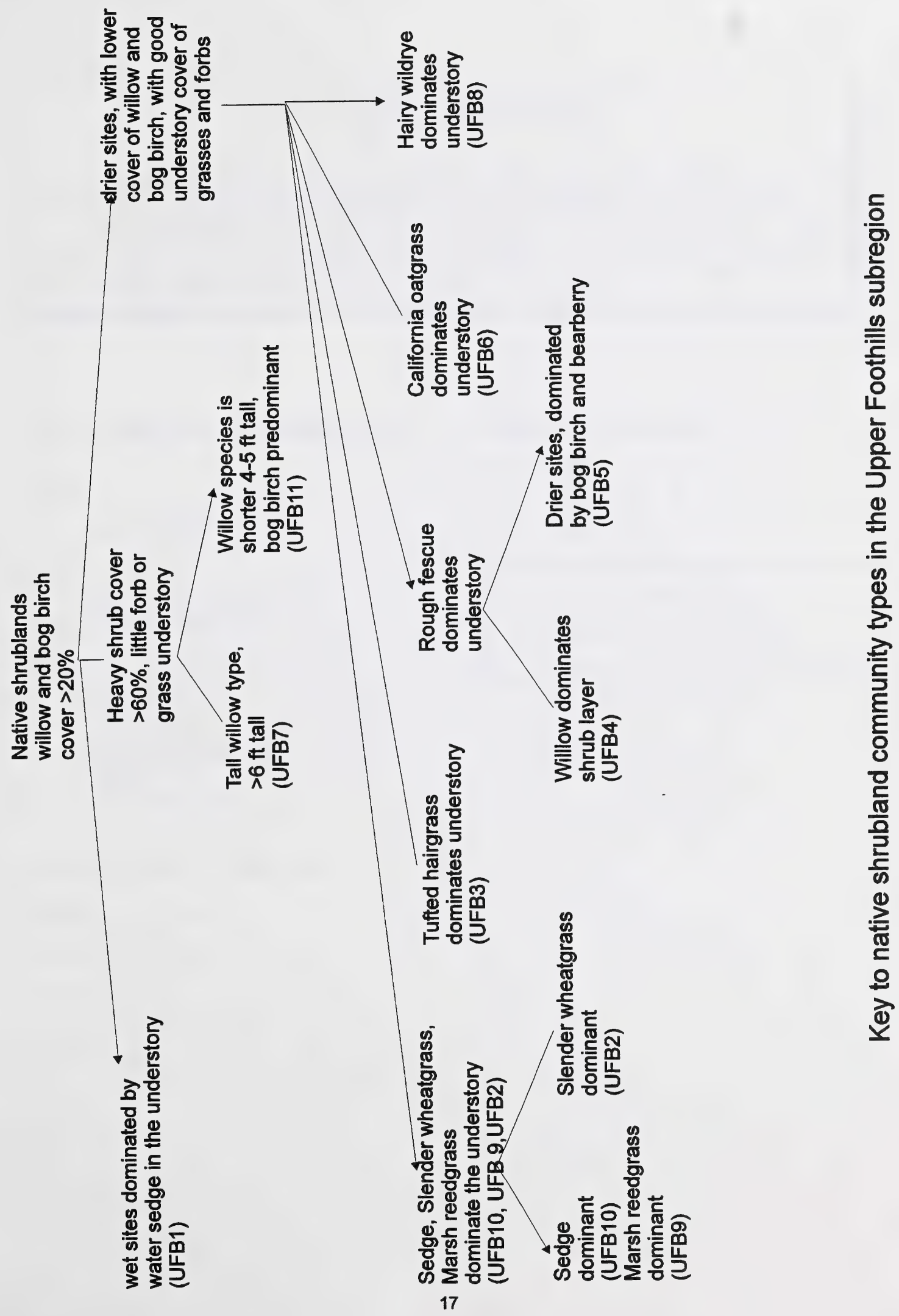





\title{
UFA1. Water sedge meadows (Carex aquatilis)
}

$\mathbf{n}=4$ Wet conditions and periodic flooding result in the formation of water sedge meadows. Bog birch and willow will invade into the drier edges of these meadows to form the Willow-bog birch/Water sedge community type.

These community types are quite productive producing nearly $2000 \mathrm{~kg} / \mathrm{ha}$ of forage, but the high water table in the spring and summer when these meadows are most palatable limits livestock use. A study in the Yukon found that crude protein on these meadows declined from a high of 10\% in May to less than 5\% in September (Bailey et al. 1992). As a result, these meadows would be rated as secondary or non-use range.

\section{Plant COMPOSITION CANopy Cover(\%)}

SHRUBS

BARCLAY'S WILLOW

(Salix barclayi)

2

FORBS

ARROW LEAVED COLTSFOOT
(Petasites sagittatus)

GRASSES

WATER SEDGE

(Carex aquatilis)

TUFTED HAIRGRASS

(Deschampsia cespitosa)

BROWNISH SEDGE

(Carex brunnescens)

\section{CARRYING CAPACITY}

ForAgE PRODUCTION IN KG/HA (+-STD. DEV.)

GRASS 1215

FORBS 774

TOTAL $1721(353)$

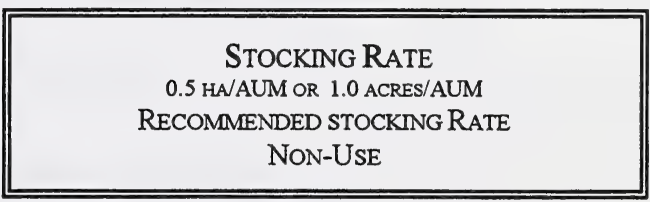

\section{ENVIRONMENTAL VARIABLES}

\author{
MOISTURE REGIME (MEAN): \\ HYGRIC (7) \\ NUTRIENT REGIME (MEAN \\ PERMESOTROPHIC (4) \\ ELEVATION: \\ 1380 - 1500 (1435) M \\ SOIL DRAINAGE (MEAN): \\ POORLY
}





\section{UFA2. Sedge-Slender wheatgrass/Meadow rue \\ (Carex praticola-Agropyron trachycaulum/Thalictrum venulosum)}

$\mathbf{n = 2}$ This community type is represented by the Cutoff Creek rangeland reference area (Willoughby 1992). The site is dominated by 3 sedge species C. praticola, C. praegracilis and C. prairea that are adapted to moist conditions. The presence of small amounts of tufted hairgrass and rough fescue indicates that this site may represent a phase of the Rough fescue-Tufted hairgrass plant community. Past heavy grazing pressure may have shifted the plant community to one dominated by sedge species or this site could be too wet for tufted hairgrass and rough fescue growth.

The forage producutivity on this community type is good. The drier site conditions compared to the water sedge meadows throughout the growing season allow for easy access by livestock. This community would be rated as primary range.

\section{Plant COMPOSITION Canopy Cover(\%)}

SHRUBS

SHRUBBY CINQUEFOIL

(Potentilla fruticosa)

BOG BIRCH

(Betula glandulosa)

FORBS

VEINY MEADOW RUE

(Thalictrum venulosum)

OLD MAN's WHISKER

(Geum triflorum)

SLENDER BLUE BEARDTONGUE

(Penstemon procerus)

YARROW

(Achillea millefolium)

SILVERY CINQUEFOIL

(Potentilla arguta)

LINDLEY's ASTER

(Aster ciliolatus)

GRASSES

SEDGE

(Carex praticola)

GRACEFUL SEDGE

(Carex praegracilis)

PRAIRE SEDGE

(Carex prairea)

SLENDER WHEATGRASS

(Agropyron trachycaulum)

2

13

8

10

6

14

12

\section{ENVIRONMENTAL VARIABLES}

MOISTURE REGIME (MEAN):

SUBHYGRIC (6)

NUTRIENT REGIME (MEAN):

PERMESOTROPHIC(4)

ELEVATION:

$1460 \mathrm{M}$

SoIl Dranage (MEAN):

MODERATELY WELL

\section{Suggested StOckING RATE \\ $0.4 \mathrm{HA} / A U M O R \quad 0.8 \mathrm{ACRES} / \mathrm{AUM}$}





\section{UFA3. Tufted hairgrass-Sedge \\ (Deschampsia cespitosa-Carex praegracilis)}

$\mathbf{n}=\mathbf{2 4}$ This community is located on moist sites that are better drained and slightly drier than the pure sedge meadows. Willoughby (1992) and Willoughby and Smith (1996), found that tufted hairgrass is a common plant species on these lowland sites throughout the Upper Foothills and lower Subalpine subregions. At lower elevations, this species appears to be replaced by Marsh reedgrass. When this community type is protected from grazing for 25-30 years, willow and bog birch expand (Willow/Tufted hairgrass-sedge c.t.) and tufted hairgrass and sedge decline (Willoughby 1992). The decline in graminoid cover also results in a decline in available forage production (2200 to $1800 \mathrm{~kg} / \mathrm{ha}$ ). Continuous heavy grazing pressure causes hairgrass to decline and the site will be invaded by Kentucky bluegrass and dandelion.

Bork (1994), found this c.t. to be the most productive type described in Willmore wilderness park. Forage production averages over $2000 \mathrm{~kg} / \mathrm{ha}$ and can vary from $800-3300 \mathrm{~kg} / \mathrm{ha}$. This community type would be rated as primary range.

\section{Plant COMPOSITION CANOPY COVER(\%)}

\section{SHRUBS}

$$
\begin{aligned}
& \text { BARCLAY'S WILLOW } \\
& \text { (Salix barclayi) }
\end{aligned}
$$

FORBS

YARROW
(Achillea millefolium)

STRAWBERRY

(Fragaria virginiana)

VEINY MEADOW RUE

(Thalictrum venulosum)

LINDLEY'S ASTER

(Aster ciliolatus)

GRACEFUL CINQUEFOIL

(Potentilla gracilis)

COMMON DANDELION

GRASSES

(Taraxacum officinale)

TUFTED HAIRGRASS

(Deschampsia cespitosa)

GRACEFUL SEDGE

(Carex praegracilis)

SLENDER WHEATGRASS

(Agropyron trachycaulum)

\section{ENVIRONMENTAL VARIABLES}

MOISTURE REGIME (MEAN):

SUBHYGRIC (6.1)

NUTRIENT REGIME (MEAN):

PERMESOTROPHIC (4.00)
ELEVATION:

$$
1303-1646(1433) \mathrm{M}
$$

\section{SoIl DRAINAGE (MEAN):}

MOD. WELL(4.2)

\section{CARRYING CAPACITY \\ FORAGE PRODUCTION IN KG/HA \\ GRASS 1403(422-2889) \\ FORBS 699(371-1572) \\ TOTAL 2189(824-3293)}

\section{SUGgested STOCKING RATE 0.4 HA/AUM OR 0.9 ACRES/AUM}





\section{UFA4. Tufted hairgrass-Sedge-Slender wheatgrass \\ (Deschampsia cespitosa-Carex spp.-Agropyron trachycaulum)}

$n=7 \quad$ This community type may be a transitional community between the willow dominated community types and the tufted hairgrass dominated grasslands. Two of the sites described in this community are represented by the inside ungrazed transect at two rangeland reference area sites. Protection from grazing for 25-35 years appears to allow willow to expand and there is a shift away from a tufted hairgrass dominated community type to a type that is dominated by slender wheatgrass, sedge and tall forb species. Continued protection from grazing and fire will likely lead to a community dominated by willow and bog birch, with little understory of forbs and grass.

\section{Plant COMPOSITION Canopy Cover(\%)}

SHRUBS

\author{
BARCLAY'S WILLOW \\ (Salix barclayi) \\ BOG BIRCH \\ (Betula glandulosa)
}

FORBS

LINDLEY'S ASTER

(Aster ciliolatus)

VEINY MEADOW RUE

(Thalictrum venulosum)

YARROW

(Achillea millefolium)

GRACEFUL CINQUEFOI

(Potentilla gracilis)

STRAWBERRY

(Fragaria virginiana)

AMERICAN VETCH

(Vicia americana)

FIREWEED

(Epilobium angustifolium)

TALL LUNGWORT

(Mertensia paniculata)

GRASSES

GRACEFUL SEDGE

(Carex praegracilis)

TUFTED HAIRGRASS

(Deschampsia cespitosa)

SLENDER WHEATGRASS

(Agropyron trachycaulum)

7

11

7

2

6

3

5

8

12
8

15

\section{ENVIRONMENTAL VARIABLES}

MOISTURE REGIME (MEAN):

MESIC-SUBHYGRIC

NUTRIENT REGIME (MEAN):

PERMESOTROPHIC (3.6)

Elevation:

$1303-1500(1367) \mathrm{M}$

SOIL DRAINAGE (MEAN):

MODERATELY WELL(3.6)

CARRYING CAPACITY

ForAge PRODUCTION IN K̇G/HA (+-STD. DEV.)

GRASS 1876(864-2416)

FORBS 986(477-1702)

TOTAL 2785(1478-4118)

\section{SugGested STOCKING RATE $0.3 \mathrm{HA} / A U M$ OR 0.7 ACRES/AUM}





\section{UFA5. Rough fescue-Tufted hairgrass \\ (Festuca scabrella-Deschampsia cespitosa)}

$\mathbf{n}=4$ This community type is located upslope from the Tufted hairgrass-Sedge community type on drier better drained soils. The drier soil conditions limit the amount of forage being produced. There was $300 \mathrm{~kg} / \mathrm{ha}$ less forage produced in the Rough fescue-Tufted hairgrass community type compared to the Tufted hairgrass-Sedge community type.

In the absence of fire and grazing this community type will become dominated by willow and bog birch (Willow/Rough fescue c.t.). Heavy grazing pressure also decreases the cover of rough fescue and tufted hairgrass and allows Kentucky bluegrass and dandelion to increase (Willoughby 1992). The dominant plant species on this community are highly palatable and the sites are easily accessible to livestock. Consequently, this community would be rated as primary range.

\section{PLANT COMPOSITION CANOPY COVER(\%)}

FORBS

SLENDER Blue Beardtongue

(Penstemon procerus)

YARROW

(Achillea millefolium)

GRACEFUL CINQUEFOIL

(Potentilla gracilis)

CHICKWEED

(Cerastium arvense)

MONKSHOOD

GRASSES

(Aconitum delphinfolium) 2

ROUGH FESCUE

(Festuca scabrella)

TUFTED HAIRGRASS

(Deschampsia cespitosa)

SLENDER WHEATGRASS

(Agropyron trachycaulum)

GRACEFUL SEDGE

(Carex praegracilis)

CALIFORNIA OATGRASS

(Danthonia californica)

5

5

3

2

24

17

4

16

3

\section{ENVIRONMENTAL VARIABLES}

MOISTURE REGIME (MEAN):

MESIC-SUBHYGRIC

NUTRIENT REGIME (MEAN):

PERMESOTROPHIC (3.80)

ElEvation:

$1370-1737(1531) \mathrm{M}$

SOIL DRAINAGE (MEAN):

MODERATELY WELL
CARRYING CAPACITY

FORAGE PRODUCTION IN KG/HA (†-STD. DEV.)

FORBS 707(166-1552)

TOTAL 1811(913-2272)
GRASS 1108(605-1797)

\section{SUGGESTED STOCKng RATE \\ $0.5 \mathrm{HA} / \mathrm{AUM}$ OR $1.1 \mathrm{ACRES} / \mathrm{AUM}$}





\section{UFA6. Rough fescue-Hairy wildrye \\ (Festuca scabrella-Elymus innovatus)}

$\mathbf{n}=\mathbf{8}$ These grasslands are located on lower, south facing slopes. They represent the transition zone from the dry Junegrass/Sage dominated south facing slopes to the moist Rough fescue and Tufted hairgrass dominated community types. Grazing pressure causes a shift away from a rough fescue, hairy wildrye dominated community to a sedge, Kentucky bluegrass dominated community (Willoughby 1992). These grasslands are fairly moist and have well developed soils which makes them very productive. This community type would be rated as primary range.

\section{Plant COMPOSITION CANOPY COVER(\%)}

SHRUBS

FORBS

\author{
BEBB'S WLLOW \\ (Salix bebbiana)
}

2

FIREWEED

(Epilobium angustifolium)

OLD MAN's WHISKERS

(Geum triflorum)

STAR FLOWEREd SOLOMON'S SEAL

(Smilacina stellata)

WILD STRAWBERRY

(Fragaria virginiana)

VEINY MEADOW RUE

(Thalictrum venulosum)

GRASSES

\section{ROUGH FESCUE}

(Festuca scabrella)

HAIRY WILDRYE

(Elymus innovatus)

SLENDER WHEATGRASS

(Agropyron trachycaulum)

KENTUCKY BLUEGRASS

(Poa pratensis)

SEDGE SPP.

(Carex spp.)

PRAIRIE SEDGE

(Carex prairea)

JUNEGRASS

(Koeleria macrantha)

2

37

9

7

2

14

3

5

\section{ENVIRONMENTAL VARIABLES}

MOISTURE REGIME (MEAN):

MESIC (5.00)

NUTRIENT REGIME (MEAN):

MESOTROPHIC (3)

ELEVATION:

$1460-1798(1633) \mathrm{M}$

Soll Dranage (MEAN):

MODERATELY WELL TO WELL
SUGGESTED STOCKING RATE

$0.5 \mathrm{HA} / A U M$ OR 1.1 ACRES/AUM

\section{CARRYING CAPACITY}

FORAGE PRODUCTION IN KG/HA (+-STD. DEV.)

GRASS 1755

FORB 278

TOTAL 1963(850-3100)

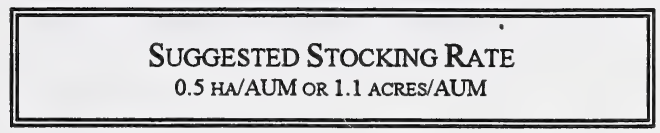





\section{UFA7. Rough fescue/Bearberry \\ (Festuca scabrella/Arctostaphylos uva-ursi)}

$\mathrm{n}=4$ This community type is similar to the Bog birch/Rough fescue/Bearberry community type but lacks the cover of bog birch. This community occupies sites that have shallow, well-drained, gravelly soils. These site conditions favour the growth of bearberry.

This community is moderately productive, but because of the poor soil conditions precautions must be taken to prevent overutilization.

\section{Plant COMPOSITION CANopy Cover(\%)}

\section{SHRUBS}

SHRUBBY CINQUEFOIL

(Potentilla fruticosa)

FORBS

BEARBERRY

(Arctostaphylos uva-ursi)

OLD MAN'S WHISKERS

(Geum triflorum)

YARROW

(Achillea millefolium)

SMOOTH LEAVED CINQUEFOIL

(Potentilla diversifolia)

GRASSES

ROUGH FESCUE

(Festuca scabrella)

SLENDER WHEATGRASS

(Agropyron trachycaulum)

SEDGE

(Carex praticola)

FRINGED BROME

(Bromus ciliatus)

HAIRY WILDRYE

(Elymus innovatus)

2

21

10

11

2

49

9

3

4

4

\section{ENVIRONMENTAL VARIABLES}

MOISTURE REGIME (MEAN): MESIC
NUTRIENT REGME (MEAN): MESOTROPHIC

ELEVATION: $1676-1829(1745) \mathrm{M}$

SoIl DRAINAGE (MEAN): WELL

\section{CARRYING CAPACITY}

FORAGE PRODUCTION IN KG/HA (+-STD. DEV.) GRASS 1023(580-1686)

FORBS 538(204-820)

TOTAL 1561(1156-1890)

\section{Suggested STOCKING RATE} $0.6 \mathrm{HA} / A U M$ OR 1.3 ACRES/AUM 



\section{UFA8. California oatgrass-Sedge \\ (Danthonia californica-Carex praegracilis)}

$\mathbf{n = 4}$ Dry, gravelly or stony soils support this moderately productive grassland that is dominated by California oatgrass. Small pockets of this community type occur throughout the Upper Foothills subregion. In the Yukon these small meadows were found to form in depressions which appeared to act as pronounced frost pockets (Bailey et al. 1992). In the Subalpine subregion these California oatgrass dominated grasslands are often associated with bog sedge (Willoughby and Smith 1996). The cold air drainage and poor nutrient quality of the soil limits the forage productivity of these sites.

\section{Plant COMPOSITION CANopy Cover(\%)}

SHRUBS

DWARF BLLBERY OR BLUEBERRY

(Vaccinium caespitosum)

SHRUBBY CINQUEFOIL

FORBS

(Potentilla fruticosa)

LINDLEY'S ASTER

(Aster ciliolatus)

WILD STRAWBERRY

(Fragaria virginiana)

OLD MAN's WHISKERS

(Geum triflorum)

ALPINE MILK VETCH

(Astragalus alpinus)

VEINY MEADOW RUE

(Thalictrum venulosum)

BLUE EYED GRASS

(Sisyrinchium montanum)

GRASSES

CALIFORNIA OATGRASS

(Danthonia californica)

GRACEFUL SEDGE

(Carex praegracilis)

SLENDER WHEATGRASS

(Agropyron trachycaulum)

SHEEP FESCUE

(Festuca saximontana)

COLUMBIA NEEDLEGRASS

(Stipa columbiana)

16

7

5

5

34

23

15

7

11

\section{ENVIRONMENTAL VARIABLES}

MOISTURE REGIME (MEAN): SUBHYGRIC(5.50)

NUTRIENT REGIME (MEAN): MESOTROPHIC (3.5)

\section{ELEVATION:}

$1400-1490$ (1425)M

SOIL DRAINAGE (MEAN):

MODERATELY WELL TO WELL

\section{SUGGESTED STOCKING RATE} $0.9 \mathrm{HA} / A U M$ OR 1.8 ACRES/AUM

\section{CARRYING CAPACITY}

FORAGE PRODUCTION IN KG/HA (+-STD. DEV.)

GRASS 731

FORBS $\quad 302$

TOTAL 1117

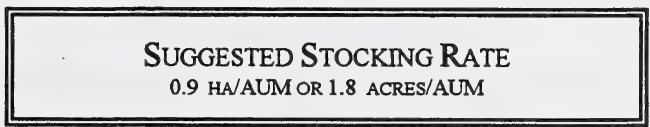





\section{UFA9. Junegrass/Sage (Koeleria macrantha/Artemisia frigida)}

$\mathbf{n}=1$ This community type occurs on steep south facing slopes, with shallow soils, overlying sandstone bedrock The majority of the vegetation are composed of drought tolerant species sage, bearberry and junegrass. The inaccessibility and fragile nature of the soils make this community type unsuitable for grazing.

This community type is very similar to the Blunt sedge-Rocky Mtn. fescue/Bearberry community described by Willoughby and Smith (1996) and the Junegrass-Hairy wildrye-Brome community described by Corns and Achuff (1982) on steep south-facing slopes in the Subalpine subregion.

\section{Plant Composition Canopy Cover(\%)}

SHRUBS

PRICKLY ROSE

(Rosa acicularis)

FORBS

BEARBERRY

(Arctostaphylos uva-ursi)

PLANNS WORMWOOD

(Artemisia campestris)

FRINGED SAGE

(Artemisia frigida)

MOUNTAIN GOLDENROD

(Solidago spathulata)

LATE YELLOW LOCOWEED

(Oxytropis monticola)

GRASSES

JUNEGRASS

(Koeleria macrantha)

SHEEP FESCUE

(Festuca saximontana)

2

5

5

5

5

7

5

\section{ENVIRONMENTAL VARIABLES}

MOISTURE REGIME (MEAN):

SUBMESIC TO SUB XERIC(3)

NUTRIENT REGIME (MEAN):

SUBMESOTROPHIC
ElEVATION:

$1560 \mathrm{M}$

SLOPE: $30 \%$

ASPECT: SOUTHERLY

SOIL DRAINAGE (MEAN):

RAPIDLY

\section{CARRYING CAPACITY}

ForAGE PRODUCTION IN KG/HA (+-STD. DEV.)

TOTAL $\quad 400$

\section{Suggested StockIng RATE}

0 HA/AUM OR 0 ACRES/AUM 



\section{UFA10. Early yellow locoweed-Bearberry/Slender wheatgrass (Oxytropis sericea-Arctostaphylos uva-ursi/Agropyron trachycaulum)}

$\mathbf{n}=1$ This community type is found scattered throughout the Upper Foothills subregion on dry, gravelly, well drained river flats. The presence of silverberry, yellow mountain avens, bearberry and early yellow locoweed are very common on these sites.

The poor soil conditions limits the forage productivity and amount of regrowth after grazing. This community type should be rated as secondary or non-use range.

\section{Plant COMPOSITION CANopy Cover(\%)}

SHRUBS

SILVERBERRY

(Elaeagnus commutata)

FORBS

BEARBERRY

(Arctostaphylos uva-ursi)

STRAWBERRY

(Fragaria virginiana)

EARLY YELLOW LOCOWEED

(Oxytropis sericea)

YARROW

(Achillea millefolium)

YELLOW MOUNTAIN AVENS

(Dryas drummondii)

GRASSES

JUNEGRASS

(Koeleria macrantha)

SHEEP FESCUE

(Festuca saximontana)

SLENDER WHEATGRASS

(Agropyron trachycaulum)

ALPINE BLUEGRASS

(Poa alpina)

SHEEP FESCUE

(Festuca saximontana)

ROUGH FESCUE

(Festuca scabrella)

\section{ENVIRONMENTAL VARIABLES}

MOISTURE REGIME (MEAN):

SUBMESIC

2

6

3

6

3

12

10

\section{Suggested Stockng RATE}

NON-USE

NUTRIENT REGIME (MEAN):

MESOTROPHIC

ELEVATION:

$1400 \mathrm{M}$

SOIL DRAINAGE (MEAN):

RAPIDLY

\section{CARRYING CAPACITY}

ForAGE PRODUCTION IN KG/HA (+-STD. DEV.)

TOTAL

500

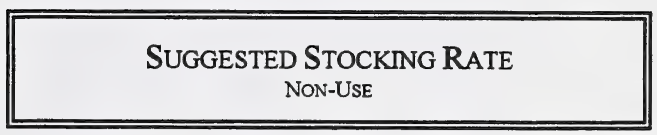





\section{UFA11. Fireweed/Hairy wildrye(Forb meadow) (Epilobium angustifolium/Elymus innovatus)}

$\mathbf{n}=\mathbf{3}$ This community type is found on moist lowland sites adjcent to the lodgepole pine and white spruce dominated forests. It represents the tranisition from the willow and grass dominated riparian areas to the conifer dominated forests. In the absence of disturbance (fire) it appears the succession of conifers into the grassy meadows shifts the species dominance away from a predominant graminoid cover to one dominated by forbs such as, fireweed, Lindley's aster and palmate leaved coltsfoot. There is also a shift in grass cover away from tufted hairgrass, rough fescue and sedge species to more shade tolerant grass species, purple oatgrass and hairy wildrye. Periodic burning of this site is required to limit tree and shrub expansion.

This community type is very productive and easily accessible to livestock. It would be rated as primary range.

\section{Plant Composition Canopy Cover(\%)}

TREES

WHITE SPRUCE

(Picea glauca)

LODGEPOLE PINE

(Pinus contorta)

SHRUBS

WILLOW SPP.

FORBS

(Salix spp.)

FIREWEED

(Epilobium angustifoliuim)

STRAWBERRY

(Fragaria virginiana)

LINDLEY'S ASTER

(Aster ciliolatus)

YARROW

(Achillea millefolium)

PALMATE LEAVED COLTSFOOT

(Petasites palmatus)

GRASSES

HAIRY WILDRYE

(Elymus innovatus)

PURPLE OATGRASS

(Schizachne purpurascens)

TUFTED HAIRGRASS

(Deschampsia cespitosa)

26

7

\section{ENVIRONMENTAL VARIABLES}

MOISTURE REGIME (MEAN):

SUBHYGRIC(6)

NUTRIENT REGIME (MEAN):

PERMESOTROPHIC

ElEvation:

1310-1454(1401)M

Soll DRanAge (MEAN):

MOD. WELL

\section{CARRYING CAPACITY}

Forage Production IN KG/HA (+-STD. DEV.)

GRASS 200

FORB 1154

TOTAL 1252

\section{SUGGESTED STOCKING RATE}

$0.7 \mathrm{HA} / \mathrm{AUM} 1.7 \mathrm{AC} / \mathrm{AUM}$ 



\section{UFA12. Rough fescue-Bog sedge \\ (Festuca scabrella-Kobresia myosuroides)}

$\mathbf{n}=\mathbf{2}$ This community is very similar to the Bog birch/Rough fescue-Bog sedge community type described by Willoughby and Smith (1996) in the Foothills ecodistrict of the Subalpine subregion. Bog sedge is well adapted to growing on dry alpine slopes and rocky ridges in the mountains. Corns and Achuff (1982), described bog sedge dominated community types on windswept ridges in the alpine subregion of Banff and Jasper National Parks.

The two sites described in this community type were described at Forty Mile flats in the Upper Clearwater Forest Land Use zone. They appear to represent the transition from the Upper Foothills to the Subalpine subregion.

\section{Plant Composition Canopy Cover(\%)}

FORBS

FIREWEED

(Epilobium angustifoliuim)

OLD MAN'S WHISKERS

(Geum triflorum)

FALSE DANDELION

(Agoseris glauca)

ALPINE HEDYSARUM

(Hedysarum alpinum)

BEARBERRY

(Arctostaphylos uva-ursi)

GRASSES

HAIRY WILDRYE

(Elymus innovatus)

ROUGH FESCUE

(Festuca scabrella)

BOG SEDGE

(Kobresia myosuroides)

SLENDER WHEATGRASS

(Agropyron trachycaulum)

SEDGE

(Carex spp.)

3

\section{ENVIRONMENTAL VARIABLES}

MOISTURE REGIME (MEAN):

MESIC

NUTRIENT REGIME (MEAN): MESOTROPHIC

ELEVATION:

$1707-1828(1768) \mathrm{M}$

SOIL DRAINAGE (MEAN):

WELL

\section{CARRYING CAPACITY}

\section{Suggested StockIng RATE}

$0.8 \mathrm{HA} / \mathrm{AUM} 1.7 \mathrm{AC} / \mathrm{AUM}$ 



\section{UFA13. Arctic rough fescue}

(Festuca altaica)

$\mathbf{n}=\mathbf{2}$ This community was described at higher elevations in Willmore Wilderness Park. Bork (1994), described this community type on alpine and subalpine slopes where climate and soil conditions are still suitable for fescue to dominate in the stand. The community has a subhygric moisture regime and is moderately well drained. Forb species such as globeflower, fleabane, monkshood and mountain heliotrope are all characteristic of these high elevation meadows.

This community is much wetter than the Rough fescue-Bog sedge community previously described and is similar to the Forb meadows community type described by Willoughby and Smith (1996) in the Subalpine subregion.

\section{PLANT COMPOSITION CANOPY COVER(\%)}

\section{FORBS}

YARROW

(Achillea millefolium)

MONKSHOOD

(Aconitum delphinifolium)

MOUNTAIN HELIOTROPE

(Valeriana sitchensis)

ALPINE HEDYSARUM

(Hedysarum alpinum)

WANDERING DAISY

(Erigeron peregrinus)

GLOBEFLOWER

(Trollius albiflorus)

\section{GRASSES}

\section{ROUGH FESCUE}

(Festuca altaica)

MOUNTAIN TIMOTHY

(Phleum commutatum)

SLENDER WHEATGRASS

(Agropyron trachycaulum)

SEDGE

(Carex spp.)

TUFTED HAIRGRASS

(Deschampsia cespitosa)

\section{ENVIRONMENTAL VARIABLES}

MOISTURE REGIME (MEAN):

SUBHYGRIC

NUTRIENT REGIME (MEAN):

MESOTROPHIC

ELEVATION:

$1510-2000(1755) \mathrm{M}$

SOIL DRAINAGE (MEAN):

MOD. WELL

\section{CARRYING CAPACITY}

Forage Production IN KG/HA (+-STD. DEV.)

GRASS 743(527-959)

FORB 372(368-375)

TOTAL 1115(895-1334)

\section{SUGGESTED STOCKING RATE}

$0.8 \mathrm{HA} / \mathrm{AUM} 1.7 \mathrm{AC} / \mathrm{AUM}$ 
1

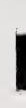

I

I

I

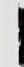

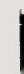




\section{UFB1. Willow-Bog birch/Water sedge (Salix spp.-Betula glandulosa/Carex aquatilis)}

$\mathbf{n}=7 \quad$ This shrub community appears on an area with very poor drainage. It is found in association with the wetter water sedge meadows. These sites are fairly productive but difficult to graze due to the moist ground conditions and heavy shrub cover which reduces access and mobility within the area. Increased flooding and prolonged waterlogging may result in the disappearance of willow and a transition to a water sedge meadow.

\section{Plant COMPOSITION CANOPY Cover(\%)}

SHRUBS

\author{
SMOOTH WLLOW \\ (Salix glauca) \\ BOG BIRCH \\ (Betula glandulosa)
}

FORBS

ARROW LEAVED COLTSFOOT

(Petasites sagittatus)

LINDLEY's ASTER

(Aster ciliolatus)

STICKY PURPLE GERANIUM

(Geranium viscosissimum)

GRACEFUL CINQUEFOL

(Potentilla gracilis)

ARCTIC ASTER

(Aster sibiricus)

GRASSES

WATER SEDGE

(Carex aquatilis)

TUFTED HAIRGRASS

(Deschampsia cespitosa)

BROWNISH SEDGE

(Carex brunnescens)

MARSH REEDGRASS

(Calamagrotis canadensis)

1

3

\section{ENVIRONMENTAL VARIABLES}

MOISTURE REGIME (MEAN):

SUBHYDRIC(8)

NUTRIENT REGIME (MEAN

PERMESOTROPHIC (4)

ELEVATION:

$$
1227-1600(1381) \mathrm{M}
$$

SOIL DRAINAGE (MEAN):

POORLY

CARRYING CAPACITY

FORAGE PRODUCTION IN KG/HA (+-STD. DEV.)

GRASS 1578(1200-3000)

FORBS 141

SHRUBS 642(284-1000)

TOTAL $1987(964-4000)$

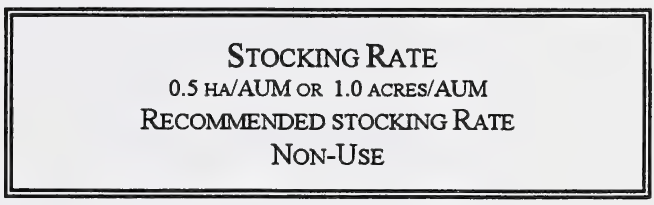





\section{UFB2. Willow/Slender wheatgrass-Sedge \\ (Salix spp./Agropyron trachycaulum-Carex spp.)}

n=3 This community type is very similar to the Tufted hairgrass-Sedge-Slender wheatgrass community type previously described. Both community types appear to represent the various stages of succession onto tufted hairgrass meadows. When these communities are protected from disturbance (fire and grazing) willow and bog birch expand and tufted hairgrass declines. Willow growth also appears to favour the growth of tall forbs (veiny meadow rue, fireweed, aster) and slender wheatgrass. Fire has played a dominant role in controlling brush encroachment in the past and continued protection will allow continued shrub expansion, resulting in a decline in forage production.

\section{Plant Composition Canopy Cover(\%)}

SHRUBS

WILLOW SPP.

(Salix spp.)

BOG BIRCH

(Betula glandulosa)

FORBS

VEINY MEADOW RUE

(Thalictrum venulosum)

OLD MAN'S WHISKERS

(Geum triflorum)

STRAWBERRY

(Fragaria virginiana)

TALL LARKSPUR

(Delphinium glaucum)

LINDLEY'S ASTER

(Aster ciliolatus)

YARROW

(Achillea millefolium)

GRASSES

SEDGE SPP.

(Carex spp.)

32

SLENDER WHEATGRASS

(Agropyron trachycaulum)

CALIFORNIA OATGRASS

(Danthonia californica)

TUFTED HAIRGRASS

(Deschampsia cespitosa)

17

10

6

15

1

14

8

20

7

6

\section{ENVIRONMENTAL VARIABLES}

MOISTURE REGIME (MEAN):

SUBHYGRIC

\section{Suggested STOCKING RATE}

$0.5 \mathrm{HA} / A U M$ OR 1.1 ACRES/AUM 



\section{UFB3. Willow/Tufted hairgrass \\ (Salix barclayi/Deschampsia cespitosa)}

$\mathbf{n = 1 5}$ This community type is found in association with the Tufted hairgrass-Sedge c.t.. Willow encroachment into a tufted hairgrass meadow eventually results in this community type. Historically fire has played an important role in the maintenance of the grassland community types in this subregion. Continued fire suppression will eventually allow willow and bog birch to invade many of these grassy meadows.

The encroachment of willow into the Tufted hairgrass-Sedge c.t. causes a decline in forage production from $2200 \mathrm{~kg} / \mathrm{ha}$ to $1200 \mathrm{~kg} / \mathrm{ha}$ for grass and forb production. Continued protection of this community type from disturbance will most likely lead to the development of a community type similar to the Willow/Slender wheatgrass (UFB2) and then to the Pussy willow shrubland (UFB7). The latter community has a high cover of willow (71\%) and very little forage for domestic livestock.

\section{Plant COMposition Canopy Cover(\%)}

SHRUBS

SMOOTH WILLOW
(Salix glauca)
Bog BIRCH
(Betula glandulosa)

FORBS

$$
\text { YARROW }
$$

WIID STRAWBERRY

(Fragaria virginiana)

LINDLEY'S ASTER

(Aster ciliolatus)

VEINY MEADOW RUE

(Thalictrum venulosum)

GRACEFUL CINQUEFOIL

(Potentilla gracilis)

PALMATE LEAVED COLTSFOOT

(Petasites palmatus)

GRASSES

TUFTED HAIRGRASS

(Deschampsia cespitosa)

SLENDER WHEATGRASS

(Agropyron trachycaulum)

GRACEFUL SEDGE

(Carex praegracilis)

PURPLE OATGRASS

(Schizachne purpurascens)

6

9

11

5

4

3

18

8

13

\section{ENVIRONMENTAL VARIABLES}

MOISTURE REGIME (MEAN):

SUBHYGRIC(6.1)

NUTRIENT REGIME (MEAN):

PERMESOTROPHIC (4.20)

ELEVATION:

$1104-1646(1311) \mathrm{M}$

\section{Suggested Stocking RATE $0.8 \mathrm{HA} / A U M$ OR 1.7 ACRES/AUM}

SoIl DRANAGE (MEAN): MOD. WELL

\section{CARRYING CAPACITY}

FORAGE PRODUCTION IN KG/HA (+-STD. DEV.)

GRASS 773(275-2307)

FORBS $417(274-695)$

SHRUBS 531(249-727)

TOTAL 2214(500-3200)

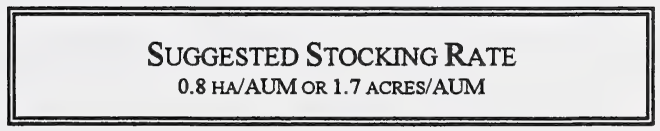




\section{UFB4. Willow/Rough fescue (Salix barclayi/Festuca scabrella)}

$\mathbf{n = 1} \quad$ This community type was described by Bork (1994) in Willmore Wilderness Park. Bork felt this community type originated from recent shrub encroachment onto rough fescue grasslands. Continued shrub expansion will result in decreasing forage productivity. Bork also felt that fescue will be replaced by wheatgrass and sedge plant species. These plants being better adapted to shading and competition from adjacent shrubs.

\section{Plant Composition Canopy Cover(\%)}

TREES

SUBALPINE FIR (Abies lasiocarpa)

SHRUBS

WILLOW SPP.

(Salix barclayi)

BOG BIRCH

FORBS

$$
\text { (Betula glandulosa) }
$$

10

ALPINE BISTORT

(Polygonum viviparum)

ALPINE BEARBERRY

(Arctostaphylos rubra)

MONKSHOOD

(Aconitium delphinifolium)

YELLOW MOUNTAIN AVENS

(Dryas drummondii)

INDIAN PAINTBRUSH

(Castelleja miniata)

GRASSES

ROUGH FESCUE

(Festuca scabrella)

GRACEFUL SEDGE

(Carex praegracilis)

7

5

4

4

12

3

\section{ENVIRONMENTAL VARIABLES}

MOISTURE REGIME (MEAN):

SUBHYGRIC

NUTRIENT REGIME (MEAN):

PERMESOTROPHIC

ELEVATION:

$1560 \mathrm{M}$

SOIL DRAINAGE (MEAN):

MODERATELY WELL

\section{CARRYING CAPACITY}

FORAGE PRODUCTION IN KG/HA (+-STD. DEV.)

GRASS 600

FORBS 200

SHRUBS 150

TOTAL 950

\section{SUGgested STOCKING RATE}

$1.0 \mathrm{HA} / A U M$ OR 2.2 ACRES/AUM 



\section{UFB5. Bog birch/Rough fescue/Bearberry (Betula glandulosa/Festuca scabrella/Arctostaphylos uva-ursi)}

$\mathbf{n = 5} \quad$ This community type is very similar to the Rough fescue-Bearberry (UFA7) type previously described, but is successionally more advanced. The soils on this community type are gravelly, drier and have a poorer nutrient regime than the other rough fescue and tufted hairgrass dominated community types. The lack of fire on this community type has allowed the shrub cover to expand, reducing forage productivity for wildlife and domestic livestock. In one study, burning a Bog birch/Rough fescue/Bearberry community type twice in 3 year intervals controlled birch growth and increased total forage production by over $40 \%$ compared to the unburned control (Bork 1990).

\section{Plant COMPOSITION CANopy Cover(\%)}

SHRUBS

BOG BIRCH

(Betula glandulosa)

WILLOW SPP.

(Salix barclayi)

2

FORBS

\section{BEARBERRY}

(Arctostaphylos uva-ursi)

LINDLEY'S ASTER

(Aster ciliolatus)

ALPINE MIIKVETCH

(Astragalus alpinus)

WIID STRAWBERRY

(Fragaria virginiana)

FIREWEED

(Epilobium angustifolium)

SLENDER BLUE BEARDTONGUE

(Penstemon procerus)

OLD MAN'S WHISKERS

GRASSES

(Geum triflorum)

ROUGH FESCUE

(Festuca scabrella)

GRACEFUL SEDGE

(Carex praegracilis)

SLENDER WHEATGRASS

(Agropyron trachycaulum)

CALIFORNIA OATGRASS

(Danthonia californica)

16

1

3

2

4

1

4

47

6

\section{ENVIRONMENTAL VARIABLES}

MoISTURE REGIME (MEAN):

MESIC-SUBHYGRIC

NUTRIENT REGIME (MEAN): MESOTROPHIC (3.)

Elevation:

1400-1798(1599) M

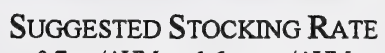

0.7 HA/AUM OR 1.6 ACRES/AUM

\section{CARRYING CAPACITY}

Forage PRODUCTION IN KG/HA (+-STD. DEV.)

GRASS 1173(856-1452)

FORBS 212(76-394)

SHRUBS 185(156-582)

TOTAL 1455(1000-1668) 



\section{UFB6. Willow/California oatgrass-Sedge \\ (Salix barcloyi/Danthonia californica-Carex spp.)}

$\mathbf{n}=\mathbf{2}$ This community type likely develops from willow encroaching onto an oatgrass dominated meadow. The oatgrass meadows are found on dry, gravelly soils. These meadows may also form in frost pockets. The spread of willow is likely caused by lack of natural disturbance, such as fire. The cover of willow on this community type is fairly extensive. This will restrict access to domestic livestock. This community type would be rated as secondary range.

\section{Plant COMPOSITION CANopy COVER(\%)}

\section{SHRUBS}

WILLOW SPP.

(Salix barclayi)

BOG BIRCH

FORBS

(Betula glandulosa)

YARROW

(Achillea millefolium)

GRACEFUL CINQUEFOIL

(Potentilla gracilis)

WIID STRAWBERRY

(Fragaria virginiana)

SLENDER BLUE BEARDTONGUE

(Penstemon procerus)

ALSIKE CLOVER

(Trifolium pratense)

FIREWEED

(Epilobium angustifolium)

VEINY MEADOW RUE

(Thalictrum venulosum)

GRASSES

CALIFORNIA OATGRASS

(Danthonia californica)

GRACEFUL SEDGE

(Carex praegracilis)

SHEEP FESCUE

(Festuca saximontana)

SLENDER WHEATGRASS

(Agropyron trachycaulum)

5

16

10

27

4

9

3

5

28

14

7

\section{ENVIRONMENTAL VARIABLES}

MOISTURE REGIME (MEAN):

SUBHYGRIC (6.00)

NUTRIENT REGIME (MEAN):

PERMESOTROPHIC (3.8)
ELEVATION:

$1400-1500(1450) \mathrm{M}$

SOIL DRAINAGE (MEAN):

MODERATELY WELL TO WELL

\section{CARRYING CAPACITY}

FoRAgE PRODUCTION IN KG/HA (+-STD. DEV.)

GRASS $\quad 598$

FORBS 418

SHRUBS $\quad 300$

TOTAL 1316

\section{Suggested StOCKING RATE}

0.7 HA/AUM OR 1.5 ACRES/AUM 



\section{UFB7. Pussy willow shrubland \\ (Salix discolor)}

$\mathbf{n}=\mathbf{2}$ This community type is common along riparian areas, swamps and fringes of marshes and lakes. It appears to be successionally more advanced than the other willow dominated community types described in this guide. As the willow cover expands over time it shades the understory vegetation resulting in a loss of forage productivity. This community type produces only $200 \mathrm{~kg} / \mathrm{ha}$ and is generally inaccessible to domestic livestock. This community type should be rated as non-use.

\section{PLANT COMPOSITION CANOPY COVER(\%)}

SHRUBS

PUSSY WILLOW

(Salix discolor)

BOG BIRCH

(Betula glandulosa)

FORBS

LINDLEY'S ASTER

(Aster ciliolatus)

6

PALMATE LEAVED COLTSFOOT

(Petasites palmatus)

WILD STRAWBERRY

(Fragaria virginiana)

GRASSES

TUFTED HAIRGRASS

(Deschampsia cespitosa)

MARSH REEDGRASS

(Calamagrostis canadensis)

3

4
ENVIRONMENTAL VARIABLES

MOISTURE REGIME (MEAN):

SUBHYGRIC(6)

NUTRIENT REGIME (MEAN):

PERMESOTROPHIC (4)

ELEVATION:

1318-1325(1322) M

SOIL DRAINAGE (MEAN):

MODERATELY WELL TO WELL

CARRYING CAPACITY

FORAGE PRODUCTION IN KG/HA (+-STD. DEV.)

TOTAL 181

SUGGESTED STOCKING RATE

NON-USE 



\section{UFB8. Willow/Hairy wildrye-Sedge \\ (Salix barclayi/Elymus innovatus-Carex spp.)}

$\mathbf{n}=2$ This plant community represents a Rough fescue-Hairy wildrye community type that has continued to undergo succession in the absence of fire and grazing. Willow cover has increased, shading the growth of grasses (rough fescue) and allowing tall-growing forbs, such as fireweed, aster and veiny meadow rue to increase. Continued protection from disturbance will allow succession to shrub and eventually tree species, which will increase shading of the understory vegetation and eventually lower forage production.

\section{Plant COMPOSITION CANopy Cover(\%)}

TREES

WHTE SPRUCE

(Picea glauca)

SHRUBS

WILLOW SPP.

(Salix barclayi)

BOG BIRCH

(Betula glandulosa)

FORBS

LINDLEY'S ASTER

(Aster ciliolatus)

VEINY MEADOW RUE

(Thalictrum venulosum)

FIREWEED

(Epilobium angustifolium)

STRAWBERRY

(Fragaria virginiana)

TALL LUNGWORT

(Mertensia paniculata)

GRASSES

GRACEFUL SEDGE

(Carex praegracilis)

HAIRY WILDRYE

(Elymus innovatus)

PURPLE OATGRASS

(Schizachne purpurascens)

SLENDER WHEATGRASS

(Agropyron trachycaulum)

1

30

21

12

6

5

11

4

32

25

22

22

\section{ENVIRONMENTAL VARIABLES}

MOISTURE REGIME (MEAN): SUBHYGRIC (6)
NUTRIENT REGIME (MEAN): PERMESOTROPHIC (3.70)

ELEVATION:

1371-1400(1386) M

SOIL DRAINAGE (MEAN): MODERATELY WELL

\section{CARRYING CAPACITY}
Forage PRODUCTION IN KG/HA (+-STD. DEV.) GRASS 2128
FORBS $\quad 477$
TOTAL 1901(900-2200)

\section{SugGested STOCKING RATE} 0.5 HAAUM OR 1.1 ACRES/AUM 



\section{UFB9. Bog birch/Sedge-Marsh reedgrass (Betula glandulosa/Carex spp.-Calamagrostis canadensis)}

$\mathbf{n}=\mathbf{2}$ This community type occupies valley drainages on soils that are saturated with water for part of the growing season This type is very similar to the Willow-Bog birch/Sedge community type, but this c.t. lacks the willow cover. It is not clear why there is no willow cover on this type. It is possible that bog birch is better adapted to growing on poor nutrient soils. The presence of marsh reedgrass may indicate the transition from the Lower Foothills to Upper Foothills subregion. Willoughby (1992), observed that marsh reedgrass was more abundant on these lowland sites at lower elevations.

The thick cover of bog birch and very wet conditions restrict access to domestic livestock. Consequently, this community type would be rated as secondary or non-use range.

\section{Plant COMPOSITION CANopy Cover(\%)}

SHRUBS

BOG BIRCH

(Betula glandulosa)

FORBS

DWARF RASPBERRY

(Rubus arcticus)

FIREWEED

(Epilobium angustifolium)

GRASSES

MARSH REEDGRASS

(Calamagrostis canadensis)

TUFTED HAIRGRASS

(Deschampsia cespitosa)

BROWNISH SEDGE

(Carex brunnescens)

WATER SEDGE

(Carex aquatilis)

10

8

6

3

\section{ENVIRONMENTAL VARIABLES}

MOISTURE REGIME (MEAN):

SUBHYGRIC (6)

NUTRIENT REGIME (MEAN):

PERMESOTROPHIC (4)

ELEVATION:

$1420 \mathrm{M}$

SoIL DRAINAGE (MEAN):

MOD. WELL (4)

\section{CARRYING CAPACITY}

FORAGE PRODUCTION IN KG/HA (+-STD. DEV.)

Total 2050* *ESTIMATE 



\section{UFB10. Willow-Bog birch/Sedge \\ (Salix barclayi-Betula glandulosa/Carex spp.)}

$\mathbf{n = 8}$ This type is very similar to the Willow-Bog birch/Water sedge community type, but the soils are drier and better drained. The drier soil conditions favour the growth of graceful sedge over water sedge.

This community type has a thick cover of bog birch and willow which restricts livestock access to the forage. This community type would be rated as secondary or non-use range.

\section{Plant COMPOSITION CANopy Cover(\%)}

SHRUBS

BOG BIRCH

(Betula glandulosa)

WILLOW SPP

(Salix barclayi)

FORBS

LINDLEY'S ASTER

(Aster ciliolatus)

YARROW

(Achillea millefolium)

STRAWBERRY

(Fragaria virginiana)

TALL LUNGWORT

(Mertensia paniculata)

VEINY MEADOW RUE

(Thalictrum venulosum)

GRASSES

GRACEFUL SEDGE

(Carex praegracilis)

SLENDER WHEATGRASS

(Agropyron trachycaulum)

HAIRY WILDRYE

(Elymus innovatus)

TUFTED HAIRGRASS

(Deschampsia cespitosa)

28

7

3

4

1

3

32

6

4

4

\section{ENVIRONMENTAL VARIABLES}

MOISTURE REGIME (MEAN): SUBHYGRIC (6.2)

NUTRIENT REGIME (MEAN): PERMESOTROPHIC (4.0)
ELEVATION:

1356-1646(1523) M

SOIL DRAINAGE (MEAN): MODERATELY WELL

\section{CARRYING CAPACITY}

ForAGE PRODUCTION IN KG/HA (+-STD. DEV.)

$$
\text { GRASS }
$$

$550(71)$

FORBS 150(71)

SHRUB 275(106)

TOTAL

\section{Suggested StOCKING RATE} 0.6 HAVAUM OR 1.4 ACRES/AUM 



\section{UFB11. Willow-Bog birch \\ (Salix barclayi-Betula glandulosa)}

$\mathbf{n}=6$ This community type is very similar to the Willow-Bog birch/Sedge c.t., but is successionally more advanced

The lack of fire has allowed continued expansion of the shrub cover. This has restricted access to livestock and lowered forage productivity. This community type would be rated as non-use for domestic livestock.

\section{Plant COMPOSITION CANOpy Cover(\%)}

\section{SHRUBS}

WIILOW SPP

(Salix barclayi)

BOG BIRCH

(Betula glandulosa)

FORBS

VEINY MEADOW RUE

(Thalictrum venulosum)

STRAWBERRY

(Fragaria virginiana)

FIREWEED

(Epilobium angustifolium)

LINDLEY'S ASTER

(Aster ciliolatus)

GRASSES

BALTIC RUSH

(Juncus balticus)

GRACEFUL SEDGE

(Carex praegracilis)

SLENDER WHEAT GRASS

(Agropyron trachycaulum)
54

19

3

7

3

6

3

4

3

\section{ENVIRONMENTAL VARIABLES}

MOISTURE REGIME (MEAN):

SUBHYGRIC (6)
NUTRIENT REGIME (MEAN):

PERMESOTROPHIC (4.00)

ELEVATION:

1375-1646(1486) M

SOIL DRAINAGE (MEAN):

MODERATELY WELL

\section{CARRYING CAPACITY}

\begin{tabular}{|c|c|}
\hline \multicolumn{2}{|c|}{ FORAGE PRODUCTION IN KG/HA (+-STD. DEV } \\
\hline GRASS & $758(476)$ \\
\hline FORBS & $487(583)$ \\
\hline SHRUBS & $333(11-5)$ \\
\hline TOTAL & $1445(805)$ \\
\hline
\end{tabular}

\section{Suggested StockIng RATE NON-USE}





\section{UPPER FOOTHILLS SUBREGION}

\section{SHRUBLANDS AND GRASSLANDS MODIFIED BY GRAZING}

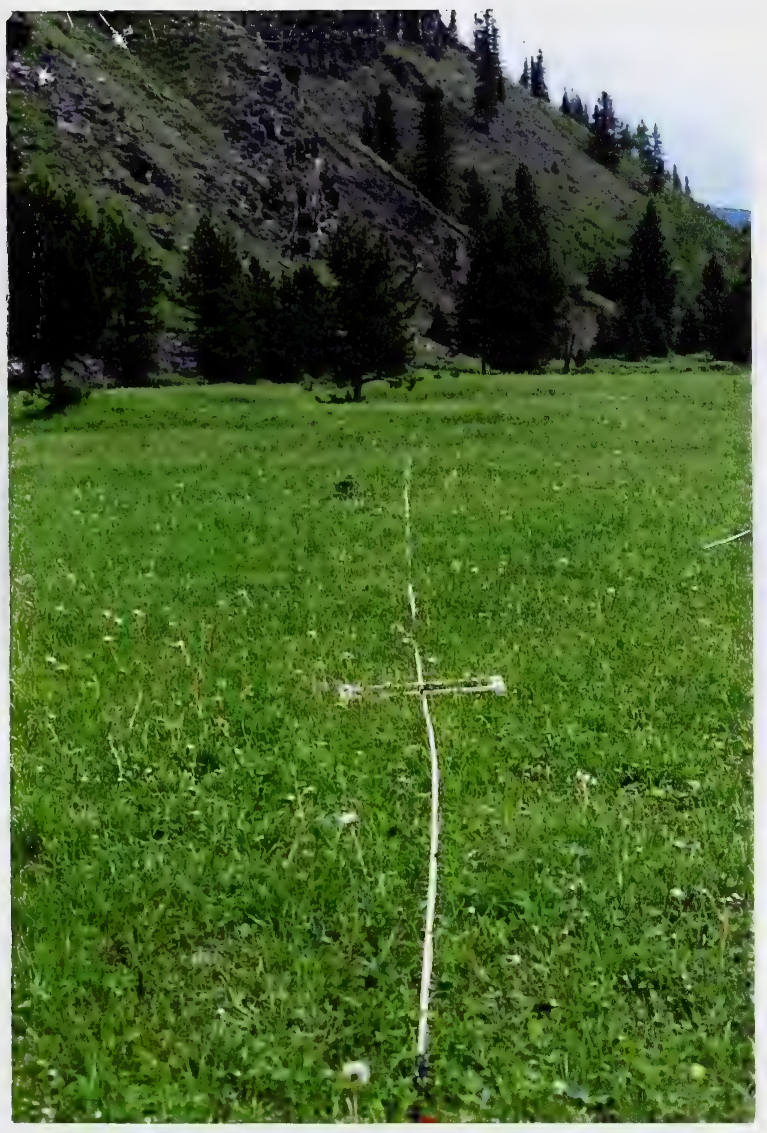

Figure 4. Heavily grazed Kentucky bluegrass/Dandelion community type 



\section{Grazing modified community types}

The grazing modified community types in the Upper Foothills subregion are outlined in Table 3. There are a few grasslands that exhibit signs of historic heavy grazing. These sites are predominantly covered by Kentucky bluegrass, dandelion and clover plant species (UFC3. Kentucky bluegrass-Sedge/Dandelion and UFC4. Kentucky bluegrass/Dandelion). Under longterm moderate grazing pressure or heavy grazing over a couple of years there is a general decline in rough fescue and tufted hairgrass and an increase in sedge and slender wheatgrass (UFC1. Slender wheatgrass-Sedge/Strawberry). When these plant communities are protected from grazing, they appear to succeed back to the original communities dominated by rough fescue and tufted hairgrass. However, when Kentucky bluegrass becomes established the community appears to revert to a rough fescue or tufted hairgrass, Kentucky bluegrass-dominated plant community (UFC5. Tufted hairgrass-Kentucky bluegrass) when protected from grazing.

The climax range condition model suggests that vegetation development will be directional, predictable and revert to the original vegetation when protected from grazing, but once Kentucky bluegrass has established itself, bluegrass appears to compete with rough fescue and tufted hairgrass for codominance. These Kentucky bluegrass communities move toward a different community rather than back to the original vegetation.

The Rocky Mtn. fescue/Graceful cinquefoil community (UFC2) appears to be a moderately to heavily grazed California oatgrass community type. The dry, gravelly conditions of this site do not appear to favour the growth of Kentucky bluegrass under heavy grazing conditions.

The Creeping red fescue/Clover (UFC7) community type represents seeded pastures and pipelines within the Upper Foothills subregion. This community type usually occurs at lower elevations, adjacent to farms and ranches where extensive modification of the native grass and shrublands have taken place. 



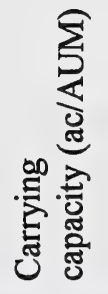

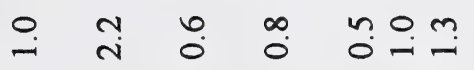

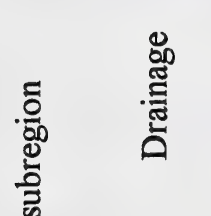

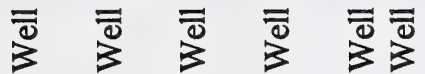

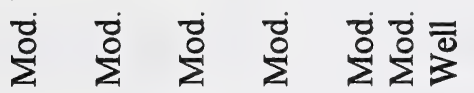

章 营

.

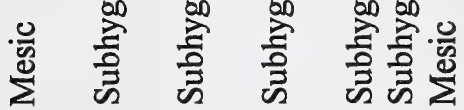

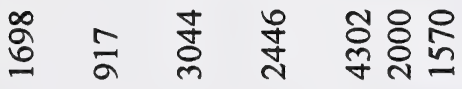

코ำ

का

륭

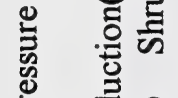

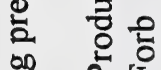

.

कूँ

ङ

군

일

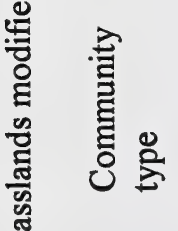

क力

్ㅠ

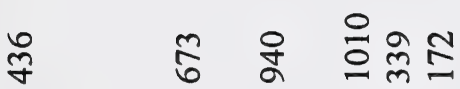

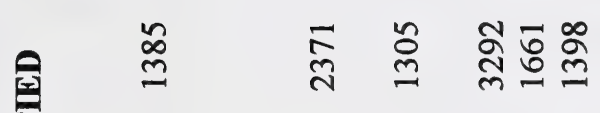

을

望 



\section{UFC1. Slender wheatgrass-Sedge/Low forbs (Agropyron trachycaulum-Carex spp./Fragaria virginiana)}

$\mathbf{n = 1 0}$ This community type appears to arise from grazing a modal fescue, tufted hairgrass community. Moderate to heavy grazing causes fescue and/or hairgrass, both decreasers, to decline in the stand. This community is very common in the valley bottoms in areas that are heavily utilized. While still quite productive, these sites have lost two of the most advantageous species. Only a reduction in grazing pressure will once again allow fescue and tufted hairgrass to become prevalent in the stand.

\section{Plant COMPOSITION CANOPY COVER(\%)}

SHRUBS

BARCLAY'S WILLOW

(Salix barclayi)

FORBS

STRAWBERRY
(Fragaria virginiana)
YARROW
(Achillea millefolium)
GRACEFUL CINQUEFOIL
(Potentilla gracilis)
LINDLEY'S ASTER
(Aster ciliolatus)
DANDELION
(Taraxacum officinale)
MEADOW RUE
(Thalictrum venulosum)

GRASSES

SLENDER WHEATGRASS

(Agropyron trachycaulum)

TUFTED HAIRGRASS

(Deschampsia cespitosa)

GRACEFUL SEDGE

(Carex praegracilis)

KENTUCKY BLUEGRASS

(Poa pratensis)

HAIRY WILDRYE

(Elymus innovatus)

FRINGED BROME

(Bromus ciliatus)

\section{ENVIRONMENTAL VARIABLES}

MOISTURE REGIME (MEAN): MESIC-SUBHYGRIC

NUTRIENT REGIME (MEAN MESOTROPHIC

ElEvation:

$$
1400-2438(1746) \mathrm{M}
$$

SOIL DRAINAGE (MEAN): MOD. WELL

\section{CARRYING CAPACITY}

FORAGE PRODUCTION IN KG/HA (+-STD. DEV.)

$$
\begin{array}{ll}
\text { GRASS } & 1385(824-2548) \\
\text { FORBS } & 436(70-868) \\
\text { TOTAL } & 1698(920-2900)
\end{array}
$$

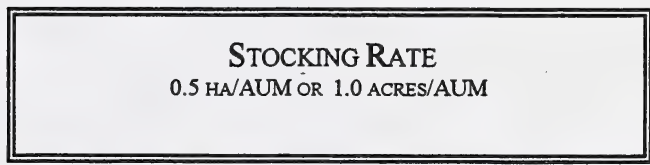





\section{UFC2. Rocky Mountain fescue/Graceful cinquefoil (Festuca brachyphylia/Potentilla gracilis)}

$\mathbf{n}=1$ This community type was described on a gravelly, well drained site adjacent to Fall creek. It appears that this site was once a California oatgrass-Sedge community type, but heavy grazing pressure has shifted the community to one dominated by unpalatable low growing graminoids and forbs, such as Rocky mountain fescue, sedge, yarrow, graceful cinquefoil and pussy toes. The dry site conditions and poor nutrient conditions do not favour the growth of Kentucky bluegrass in this community type. This community type would benefit from a deferred rotational grazing system, where the community is rested every other year.

\section{Plant COMPOSITION CANopy Cover(\%)}

FORBS

WIID STRAWBERRY
(Fragaria virginiana)
GRACEFUL CINQUEFOIL
(Potentilla gracilis)
YARROW
(Achillea millefolium)
ALPINE MIIKVETCH
(Astragalus alpinus)
ROSEY PUSSY TOES
(Antennaria rosea)
RED SEEDED DANDELION
(Taraxacum laevigatum)

GRASSES

ROCKY MOUNTAIN FESCUE

(Festuca brachyphylla)

BROWNISH SEDGE

(Carex brunnescens)

SLENDER WHEATGRASS

(Agropyron trachycaulum)

CALIFORNIA OATGRASS

(Danthonia californica)

2

13

8

6

2

2

21

5

4

4

\section{ENVIRONMENTAL VARIABLES}

MOISTURE REGIME (MEAN): SUBHYGRIC

\section{SUGgested STOCKING RATE}

1.0 HAAUM OR 2.2 ACRES/AUM 



\section{UFC3. Kentucky bluegrass/Clover-Dandelion (Poa pratensis/Trifolium spp.-Taraxacum officinale)}

$\mathbf{n = 1 0}$ This community type develops when the modal tufted hairgrass and sedge dominated communities are grazed heavily for prolonged periods of time. Willoughby (1992), felt these grasslands exhibited signs of historic heavy grazing pressure. He felt under long-term moderate grazing or heavy grazing over a couple of years rough fescue and tufted hairgrass decline and sedge, slender wheatgrass, and low growing forbs increase. When these plant communities are protected from grazing, they appear to succeed back to the original communities dominated by rough fescue and tufted hairgrass. However, when Kentucky bluegrass becomes established the community appears to revert to a rough fescue or tufted hairgrass, Kentucky bluegrass dominated plant community.

These community types are highly productive for domestic livestock during the growing season, but the poor quality of Kentucky bluegrass, particularly, in the dormant season limits the use of these community types for wildlife.

\section{Plant COMPOSITION CANopy Cover(\%)}

FORBS

\section{DANDELION}

(Taraxacum officinale)

WILD STRAWBERRY

(Fragaria virginiana)

CLOVER

(Trifolium repens)

YARROW

(Achillea millefolium)

GRACEFUL CINQUEFOII

(Potentilla gracilis)

VEINY MEADOW RUE

(Thalictrum venulosum)

GRASSES

KENTUCKY BLUEGRASS

(Poa pratensis)

SLENDER WHEATGRASS

(Agropyron trachycaulum)

TUFTED HAIRGRASS

(Deschampsia cespitosa)

4

27

13

12

6

57

5

1

\section{ENVIRONMENTAL VARIABLES}

MOISTURE REGIME (MEAN)

SUBHYGRIC(6)

NUTRIENT REGIME (MEAN):

PERMESOTROPHIC (4.00)

\section{CARRYING CAPACITY}

FORAGE PRODUCTION IN KG/HA (+-STD. DEV.)

GRASS 2371(621-4316)

FORBS 673(153-2102)

TOTAL 3044(1242-4686)
SUGGESTED STOCKING RATE $0.3 \mathrm{HA} / A U M$ OR 0.6 ACRES/AUM 



\section{UFC4. Kentucky bluegrass-Sedge/Dandelion (Poa pratensis-Carex spp./Taraxacum officinale)}

$\mathbf{n}=7$ This community type is similar to the Kentucky bluegrass/Clover-Dandelion community type., but it has not been grazed as heavily. There is still an abundance of native plant species such as veiny medow rue, slender wheatgrass, tufted hairgrass and sedge, but there has been an increase in grazing resistant species, such as Kentucky bluegrass, dandelion and clover. If this community type is protected from grazing it will probably revert back to a Tufted hairgrass-Kentucky bluegrass dominated type (Willoughby 1992). Kentucky bluegrass once established appears to be a successful competitor.

These Kentucky bluegrass dominated community types are very productive, but they have lost two of the most advantageous species (tufted hairgrass, rough fescue). The forage quality of these native species is much better, particularly in the dormant season.

\section{Plant Composition Canopy Cover(\%)}

FORBS

\section{DANDELION}

(Taraxacum officinale)

YARROW

(Achillea millefolium)

STRAWBERRY

(Fragaria virginiana)

VEINY MEADOW RUE

(Thalictrum venulosum)

GRACEFUL CINQUEFOII

(Potentilla gracilis)

GRASSES

KENTUCKY BLUEGRASS

(Poa pratensis)

SLENDER WHEATGRASS

(Agropyron trachycaulum)

TUFTED HAIRGRASS

(Deschampsia cespitosa)

SEDGE SPP.

(Carex spp.)

CREEPING RED FESCUE

(Festuca rubra)
36

10

7

13

1

\section{ENVIRONMENTAL VARIABLES}

MOISTURE REGIME (MEAN):

SUBHYGRIC (5.60)

NUTRIENT REGIME (MEAN):

PERMESOTROPHIC (3.90)

9

5

ELEVATION:

$1150-1660(1419) \mathrm{M}$

SOIL DRAINAGE (MEAN):

MODERATELY WELL
CARRYING CAPACITY

FORAGE PRODUCTION IN KG/HA (+-STD. DEV.)

GRASS 1305(1020-2169)

FORBS 940(259-1962)

TOTAL 2446(1491-3159)

\section{Suggested STOCKING RATE} $0.4 \mathrm{HA} / A U M$ OR 0.8 ACRES/AUM 



\section{UFC5. Tufted hairgrass-Kentucky bluegrass \\ (Deschampsia cespitosa-Poa pratensis)}

$\mathbf{n}=\mathbf{2}$ This community type is similar to the other Kentucky bluegrass dominated community types, but grazing pressure has been lighter or it was heavy and then became more moderate because of reduced stocking rates or rotational grazing. Willoughby (1992), found that tufted hairgrass could compete with Kentucky bluegrass in the absence of grazing, but it appears that once Kentucky bluegrass is established it remains to form a stable community type.

\section{PLANT COMPOSITION CANOPY COVER(\%)}

FORBS

$$
\begin{aligned}
& \text { DANDELION } \\
& \text { (Taraxacum officinale) } \\
& \text { YARROW } \\
& \text { (Achillea millefolium) } \\
& \text { STRAWBERRY } \\
& \text { (Fragaria virginiana) } \\
& \text { VEINY MEADOW RUE } \\
& \text { (Thalictrum venulosum) } \\
& \text { GRACEFUL CINQUEFOI } \\
& \text { (Potentilla gracilis) }
\end{aligned}
$$

GRASSES

\section{KENTUCKY BLUEGRASS \\ (Poa pratensis)}

SLENDER WHEATGRASS

(Agropyron trachycaulum)

TUFTED HAIRGRASS

(Deschampsia cespitosa)

SEDGE SPP.

(Carex spp.)

ROUGH FESCUE

(Festuca scabrella)

10

68

3

\section{ENVIRONMENTAL VARIABLES}

MOISTURE REGIME (MEAN):

SUBHYGRIC (6)

NUTRIENT REGIME (MEAN):

PERMESOTROPHIC (4)

ELEVATION:

$1300-1500(1400) \mathrm{M}$

SOIL DRANAGE (MEAN):

MODERATELY WELL

\section{CARRYING CAPACITY}

FORAGE PRODUCTION IN KG/HA (+-STD. DEV.)

GRASS 3292

FORBS 1010

TOTAL 4302

\section{Suggested StockING RATE \\ 0.2 HA/AUM OR 0.5 ACRES/AUM}





\section{UFC6. Sedge-Tufted hairgrass \\ (Carex spp.-Deschampsia cespitosa)}

$\mathbf{n = 7} \quad$ This community type was described at Harrison Flats in the Upper Clearwater River valley. It appears to represent a Tufted hairgrass-Sedge community that was heavily grazed in the past and now is rested and only lightly utilized. It appears that the heavy grazing pressure was not prolonged enough to allow Kentucky bluegrass invasion. It is also possible that Kentucky bluegrass is not predominant on this site becasue of lack of seed source in these isolated sites. It is likely with continued protection from grazing this community type will succeed back to a modal Tufted hairgrass-Sedge dominated community type.

\section{Plant Composition Canopy Cover(\%)}

FORBS

DANDELION
(Taraxacum officinale)
YARROW
(Achillea millefolium)
STRAWBERRY
(Fragaria virginiana)
VEINY MEADOW RUE
(Thalictrum venulosum)
GRACEFUL CINQUEFOI
(Potentilla gracilis)

GRASSES

KENTUCKY BLUEGRASS
(Poa pratensis)
SLENDER WHEATGRASS

(Agropyron trachycaulum)

TUFTED HAIRGRASS

(Deschampsia cespitosa)

SEDGE SPP.

(Carex spp.)

ROUGH FESCUE

(Festuca scabrella)

BALTIC RUSH

(Juncus balticus)

\section{ENVIRONMENTAL VARIABLES}

\section{MOISTURE REGIME (MEAN):}

SUBHYGRIC (6)

\section{CARRYING CAPACITY}

FORAGE PRODUCTION IN KG/HA (+-STD. DEV.)

GRASS 1661(724-3208)

FORBS 339(72-588)

TOTAL 2000(932-2740)
Suggested StOcking RATE 0.5 HAVAUM OR 1.0 ACRES/AUM 



\section{UFC7. Creeping red fescue-Clover (Festuca rubra-Trifolium spp.)}

$\mathbf{n = 1 0}$ This community type was described at lower elevations, adjacent to farms and ranches in the Upper Foothills subregion. This community represents native communities that have been disturbed and planted to creeping red fescue. These include pipelines, roadsides and cultivated pastures. Sundquist et al. (1996), felt this community type developed when a site which was seeded to Creeping red fescue-timothy-clover and receives low levels of use. Creeping red fescue spreads throughout the site by creeping rhizomes and chokes out the timothy by forming a dense matt of litter. This community type is normally considered to be in good or excellent condition.

\section{Plant COMPOSITION Canopy COVER(\%)}

FORBS

DANDELION

(Taraxacum officinale) 5

YARROW

(Achillea millefolium)

3

STRAWBERRY

(Fragaria virginiana)

ClOVER SPP.

(Trifolium repens, $T$. hybridum)

GRACEFUL CINQUEFOIL

(Potentilla gracilis)

GRASSES

KENTUCKY BLUEGRASS

(Poa pratensis)

SLENDER WHEATGRASS

(Agropyron trachycaulum)

TUFTED HAIRGRASS

(Deschampsia cespitosa)

SEDGE SPP.

(Carex spp.)

CREEPING RED FESCUE

(Festuca rubra)

TIMOTHY

(Phleum pratense)
12

1

1

1

25

6

\section{ENVIRONMENTAL VARIABLES}

MOISTURE REGIME (MEAN): MESIC

NUTRIENT REGIME (MEAN): MESOTROPHIC (4)

ELEVATION:

$1212-1485(1310) \mathrm{M}$

SOIL DRAINAGE (MEAN):

MODERATELY WELL

\section{CARRYING CAPACITY}

FORAGE PRODUCTION IN KG/HA (+-STD. DEV.)

GRASS 1398(550-2338)

FORBS 172(20-368)

TOTAL $1570(668-2706)$

\section{Suggested Stocking Rate}

0.6 HA/AUM OR 1.3 ACRES/AUM 



\section{UPPER FOOTHILLS SUBREGION}

\section{DECIDUOUS COMMUNITY TYPES}

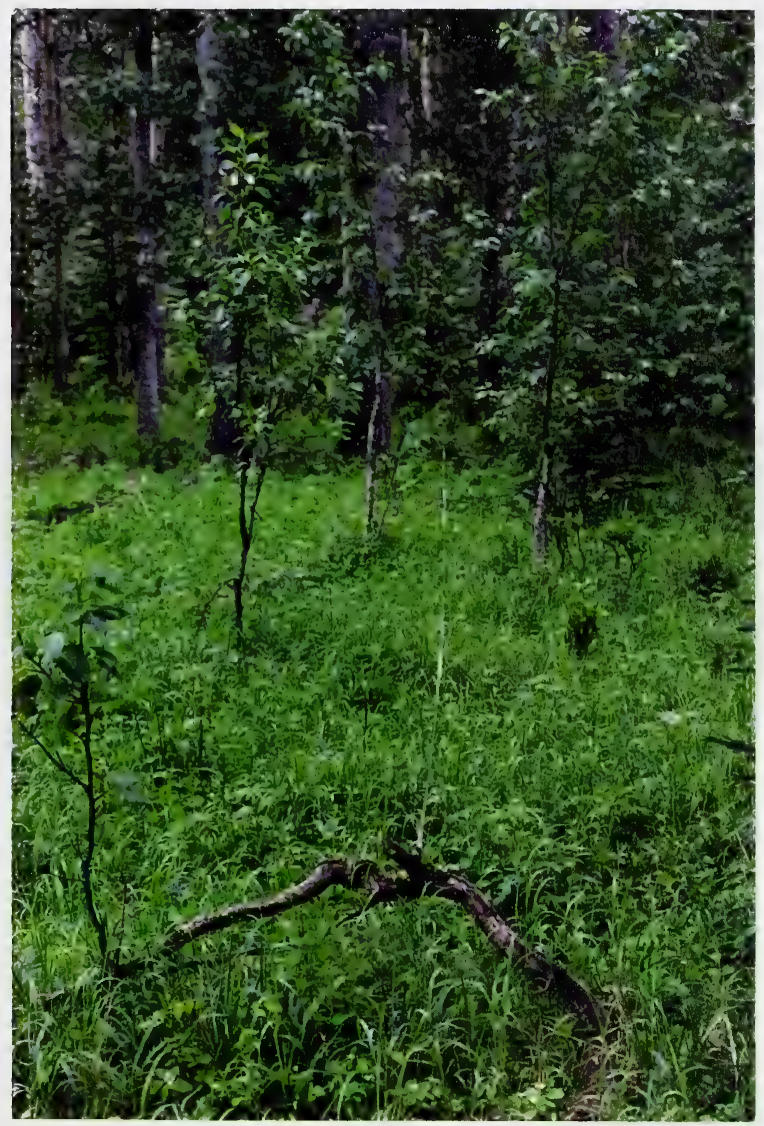

Figure 5. Aspen/Rose/Hairy wildrye community type on south facing slopes in the Upper Foothills subregion 



\section{Deciduous community types}

The four deciduous community types described in the Upper Foothills subregion are outlined in Table 4. Deciduous types are rare in this subregion. The cool climate severely restricts the growth of deciduous tree species (Strong and Leggat 1992). As a result, aspen and balsam poplar are generally found on south facing slopes where the increased insolation permits colonization.

$\mathrm{The} \mathrm{Pb}-\mathrm{Sw} / \mathrm{Willow} /$ Yellow Mtn. avens community type (UFD2) is representative of the gravelly floodplains adjacent to rivers and streams. The Aw/Rose/Hairy wildrye community type (UFD3) and Aw-Sw/Buffaloberry/Hairy wildrye are found on dry south facing slopes throughout the region. The Aw-Sw/Buffaloberry/Hairy wildrye community type appears to be successionally more advanced with slightly acidic soils than the Aw/Rose/Hairy wildrye community type.

Finally, the Aw-P1/Purple oatgrass type more closely resembles an overgrazed shrubland adjacent to Fall creek. 



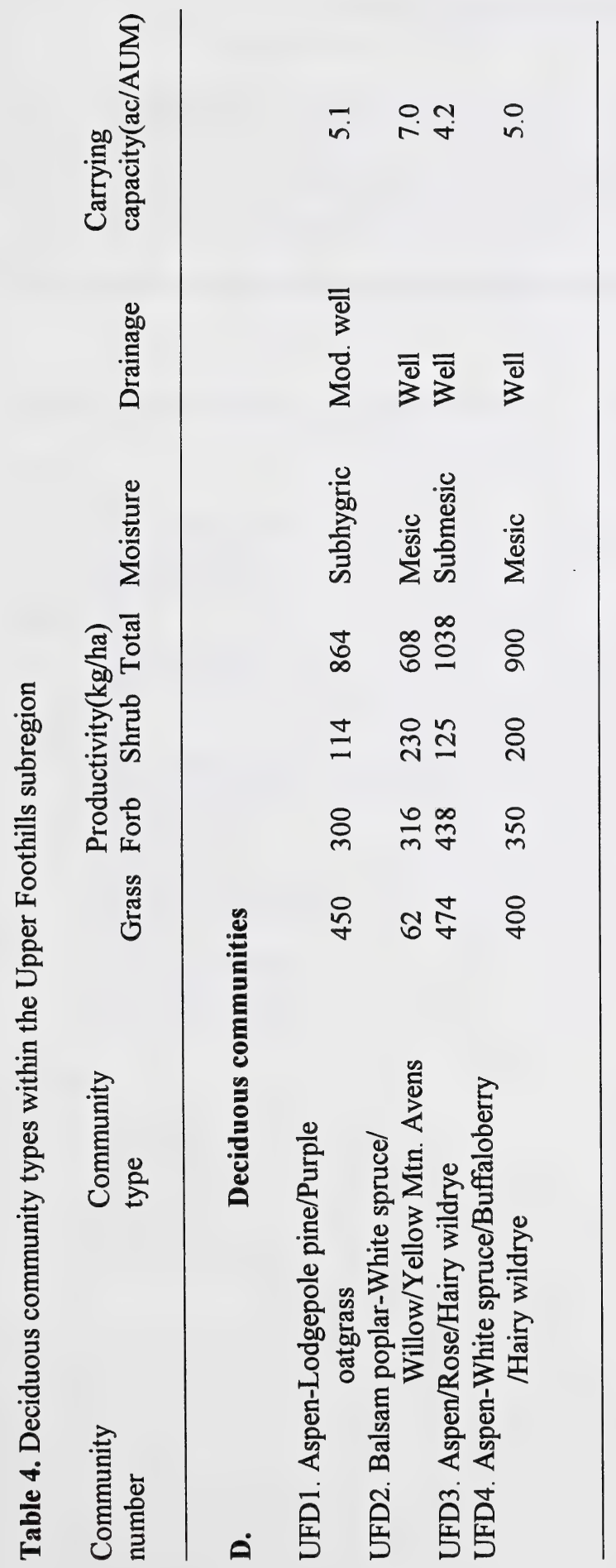

in 



\section{UFD1. Aspen-Lodgepole pine/Purple oatgrass \\ (Populus tremuloides-Pinus contorta/Schizachne purpurascens)}

$\mathbf{n}=1$ This community type was described along the flood plain of Fall Creek. It is a willow shrubland with scattered mature aspen and pine trees that has been heavily grazed in the past. The heavy grazing pressure has reduced the cover of shrubs and allowed purple oatgrass to increase. The higher moisture and nutrient content of the site allows for good regrowth after grazing. The present community structure is well suited to livestock grazing, but heavy grazing pressure along riparian areas can eventually lead to streambank erosion. This area would benefit from a rotational grazing system.

\section{Plant COMPOSITION CANopy Cover(\%)}

TREES

\author{
ASPEN \\ (Populus tremuloides) \\ LODGEPOLE PINE \\ (Pinus contorta)
}

SHRUBS

PRICKLY ROSE

(Rosa acicularis)

FORBS

STRAWBERRY

(Fragaria virginiana)

LINDLEY's ASTER

(Aster ciliolatus)

FIREWEED

(Epilobium angustifolium)

YARROW

(Achillea millefolium)

BUNCHBERRY

(Cornus canadensis)

GRASSES

PURPLE OATGRASS

(Schizachne purpurascens)

ROCKY MOUNTAIN FESCUE

(Festuca brachyphylla)

HAIRY WILDRYE

(Elymus innovatus)

\section{ENVIRONMENTAL VARIABLES}

MOISTURE REGIME (MEAN): SUBHYGRIC

10

5

NUTRIENT REGIME (MEAN

PERMESOTROPHIC (4)

ELEVATION:

\section{$1345 \mathrm{M}$}

SOIL DRAINAGE (MEAN): MOD. WELL

\section{CARRYING CAPACITY}

FORAGE PRODUCTION IN KG/HA (+-STD. DEV.)
$\begin{array}{ll}\text { GRASS } & 450 \\ \text { FORBS } & 300 \\ \text { SHRUBS } & 114 \\ \text { TOTAL } & 864\end{array}$

\section{STOCKING RATE}

$2.1 \mathrm{HA} / A U M$ OR 5.1 ACRES/AUM 


\section{UFD2. Balsam poplar-White spruce/Willow/Yellow Mountain Avens (Populus balsamifera-Picea glauca/Salix spp./Dryas drummondii)}

$\mathbf{n}=1$ This community type is common throughout the Upper Foothills subregion on gravelly floodplains along rivers and streams. It is similar to community UFA10, but successionally more advanced. This type is dominated by balsam poplar with and understory of spruce in the later successional stages. This particular stand was fairly young with the tree canopy being less than $5 \mathrm{~m}$ tall. Yellow mountain avens is a common pioneer species on gravelly river bars, and rocky slopes up into the alpine tundra (MacKinnon et al. 1992). As this community succeeds towards a mature forest yellow mountain avens will undoubtably decline in cover.

The forage production on this community type. is very low. The poor nutrient status of the soil limits the growth of grasses, forbs and shrubs. As a result, this community type would be rated as non-use range.

\section{Plant Composition Canopy Cover(\%)}

TREES

\author{
BALSAM POPLAR \\ (Populus balsamifera) \\ WHITE SPRUCE \\ (Picea glauca)
}

7

5

SHRUBS

WILLOW SPP.

(Salix spp.)

BUFFALOBERRY

(Shepherdia canadensis)

FORBS

WIID STRAWBERRY

(Fragaria virginiana)

YELLOW MOUNTAIN AVENS

(Dryas drummondii)

ALPINE HEDYSARUM

(Hedysarum alpinum)

SCOURING RUSH

(Equisetum scirpoides)

ALPINE MIIKVETCH

(Astragalus alpinus)

BEARBERRY

GRASSES

(Arctostaphylos uva-ursi)

BLUNT SEDGE

(Carex obtusata)
16

11

11

4

3

3

\section{ENVIRONMENTAL VARIABLES}

MoISTURE REGME (MEAN):

MESIC

NUTRIENT REGIME (MEAN): MESOTROPHIC

ELEVATION:

SOIL DRAINAGE (MEAN):

WELL

\section{CARRYING CAPACITY}

ForAGE PRODUCTION IN KG/HA (+-STD. DEV.)

GRASS 62

FORBS 316

SHRUBS 230

TOTAL 608

\section{Suggested STOCKING RATE}

$3 \mathrm{HA} / A U M$ OR 7 ACRES/AUM 



\section{UFD3. Aspen/Rose/Hairy wildrye \\ (Populus tremuloides/Rosa acicularis/Elymus innovatus)}

$\mathbf{n}=4$ This community type is typical of aspen forest types found throughout the Upper Foothills subregion on south facing slopes. The dry site conditions and high solar insolation favours the growth of grasses and forbs rather than shrubs. The canopy cover of aspen is also noticeably lower on this community type. This community type is similar to the Aw-Sw/Buffaloberry/Hairy wildrye community. described in Willmore Wilderness Park, but the absence of buffaloberry distinguishes this type from the Willmore type. This community is moderately productive for domestic livestock. This community would be rated as secondary range.

\section{Plant COMPOSITION Canopy Cover(\%)}

TREES

$$
\begin{aligned}
& \text { TREMBLING AsPEN } \\
& \text { (Populus tremuloides) }
\end{aligned}
$$

SHRUBS

PRICKL Y ROSE

(Rosa acicularis)

WILLOW SPP.

(Salix sp.)

FORBS

LINDLEY'S ASTER

(Aster ciliolatus)

WILD STRAWBERRY

(Fragaria virginiana)

TALL LUNGWORT

(Mertensia paniculata)

CREAM COLORED VETCHLING

(Lathyrus ochroleucus)

VEINY MEADOW RUE

(Thalictrum venulosum)

GRASSES

HAIRY WILD RYE

(Elymus innovatus)

PURPLE OATGRASS

(Schizachne purpurascens)

SLENDER WHEATGRASS

(Agropyron trachycaulum)

\section{ENVIRONMENTAL VARIABLES}

MOISTURE REGIME (MEAN): SUBMESIC (4.30)

NUTRIENT REGIME (MEAN): MESOTROPHIC (3.30)

ELEVATION:

$$
1440-1515(1493) \mathrm{M}
$$

SOIL DRAINAGE (MEAN):

WELL

\section{CARRYING CAPACITY}

FORAGE PRODUCTION IN KG/HA (+-STD. DEV.)
$\begin{array}{ll}\text { GRASS } & 474(486) \\ \text { FORBS } & 438(383) \\ \text { SHRUBS } & 125(118) \\ \text { TOTAL } & 1038(985)\end{array}$

\section{Suggested Stocking Rate}

$1.8 \mathrm{HA} / \mathrm{AUM}$ OR 4.2 ACRES/AUM 



\section{UFD4. Aspen-White spruce/Buffaloberry/Hairy wildrye (Populus tremuloides-Picea glauca/Shepherdia canadensis/Elymus innovatus)}

$\mathbf{n = 1}$ This community type was described along lower, south facing slopes and river terraces throughout Willmore Wilderness Park. Bork (1994), found this c.t. to be uncommon throughout Willmore, but pockets of this type were found along the Smoky, Sulphur and Sheep rivers on the North side of the Park. Bork felt that frequent disturbance and/or arid conditions resulted in the aspen dominated overstory. He felt if left undisturbed the community type would eventually succeed to a coniferous forest. This community type is very similar to the Aw/Buffaloberry type described by Youngblood (1993) in Alaska and the Aw/Rose/Hairy wildrye community type previously described near Rocky Mtn. House. The presence of buffaloberry distinguishes this northern type from the more southern rose type. The presence of buffaloberry may indicate a higher $\mathrm{pH}$ and lower nutrient status. Beckingham (1994), described Aw/Buffaloberry stands on lower $\mathrm{pH}$ sites.

This community type provides a good forage base for domestic livestock. In Willmore this community type is often located in close proximity to the trails and camps used by outfitters and recreationalists.

\section{Plant COMposition Canopy Cover(\%)}

TREES

\section{TREMBLING ASPEN}

(Populus tremuloides)

BALSAM POPLAR

(Populus balsamifera)

WHITE SPRUCE

(Picea glauca)

SHRUBS

\section{BUFFALOBERRY}

(Shepherdia canadensis)

PRICKLY ROSE

(Rosa acicularis)

WILLOW SPP.

(Salix spp.)

BRACTED HONEYSUCKLE

(Lonicera involcrata)

FORBS

\section{BUNCHBERRY}

(Cornus canadensis)

FIREWEED

(Epilobium angustifolium)

TWIN-FLOWER

(Linnaea borealis)

SHOWY ASTER

(Aster conspicuus)

STRAWBERRY

GRASSES
52

12

11

18

7

5

4

3

4

4

3

HAIRY WIID RYE

(Elymus innovatus)

18

7

5

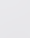

MARSH REEDGRASS

(Calamagrostis canadensis)

5

\section{2}

2

1

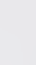





\section{UPPER FOOTHILLS SUBREGION}

\section{CONIFER COMMUNITY TYPES}

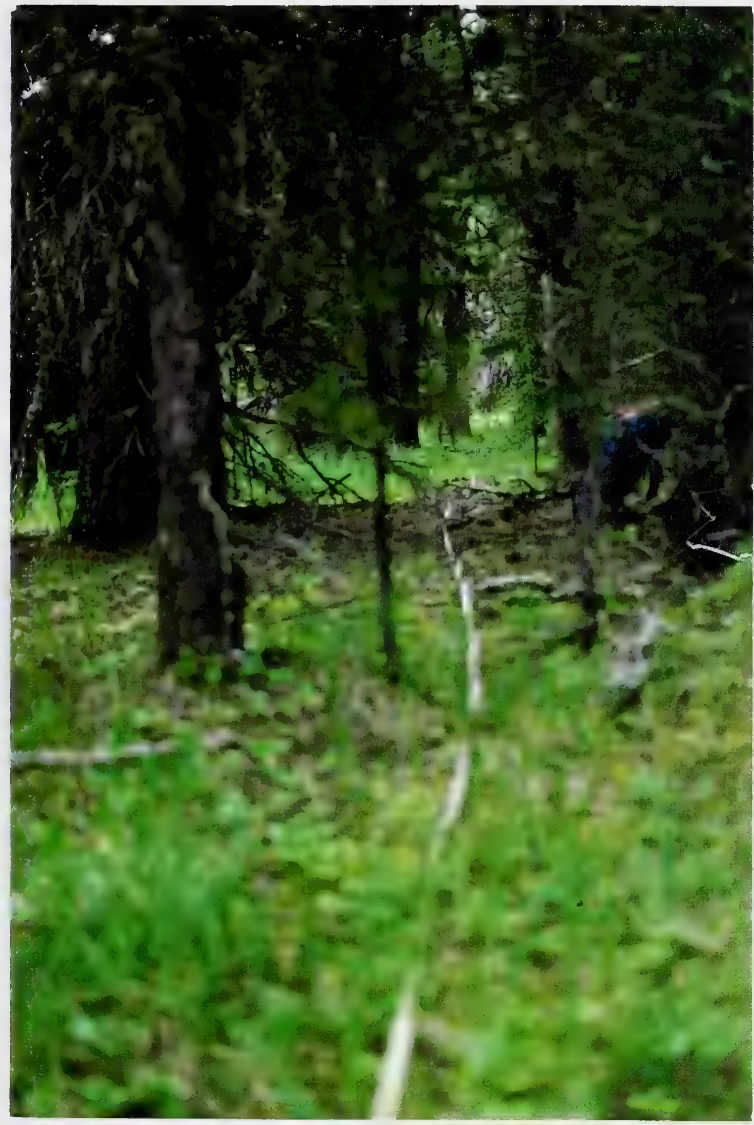

Figure 6. The Lodgepole-White spruce/Bunchberry community is the dominant conifer community type in the Upper Foothills subregion. 



\section{Conifer community types}

Lodgepole pine dominates the overstory vegetation of the mesic reference sites in the Upper Foothills subregion. Typical Lodgepole pine forests are represented by the Lodgepole pine/Bog cranberry community type (UFE1) and Lodgepole pine/Marsh reedgrass community type (UFE4). Secondary succession is by white spruce and leads to the formation of the Lodgepole pine-White spruce/Bunchberry community type (UFE2). Continued succession on wetter sites in the absence of disturbance leads to a White spruce/Horsetail/Moss dominated community type (UFE6).

Wetter, subhygric sites can be dominated by lodgepole pine, black spruce or white spruce. Many of these sites have a predominant willow understory (Lodgepole pine/Willow/Moss (UFE3) or Sw/Willow(UFE7)). These types appear to represent continued succession from the native shrub and grassland community types. Succession in the absence of disturbance on these sites will be to white spruce. The White spruce/Willow community type (UFE7) appears to be typical of a climax forest on these subhygric sites.

Black spruce dominates poorly drained depressional areas (Black spruce/Willow (UFE5). These sites have a high water table throughout most of the year. Organic accumulations are common as a result of poor drainage conditions and low oxygen availability (Strong and Leggat 1992).

Dry south facing slopes are typically dominated by deciduous aspen forests, with succession to a White spruce/Bearberry (UFE8) and lodgepole pine bearberry/hairy wildrye dominated community types (Beckingham et al. 1996). A White spruce/Juniper (UFE9) community type was described on fine-textured, calcareous loess deposits, with high $\mathrm{pH}$ 's near Brule lake. The deposits blow out of the Athabasca river valley from Jasper National Park.

The conifer forest types are generally unsuitable for livestock grazing and are typically rated as non-use.

The nine coniferous community types described in the Upper Foothills subregion are outlined in Table 5. A more complete description of coniferous community types can be found in Beckingham et al. (1996). 



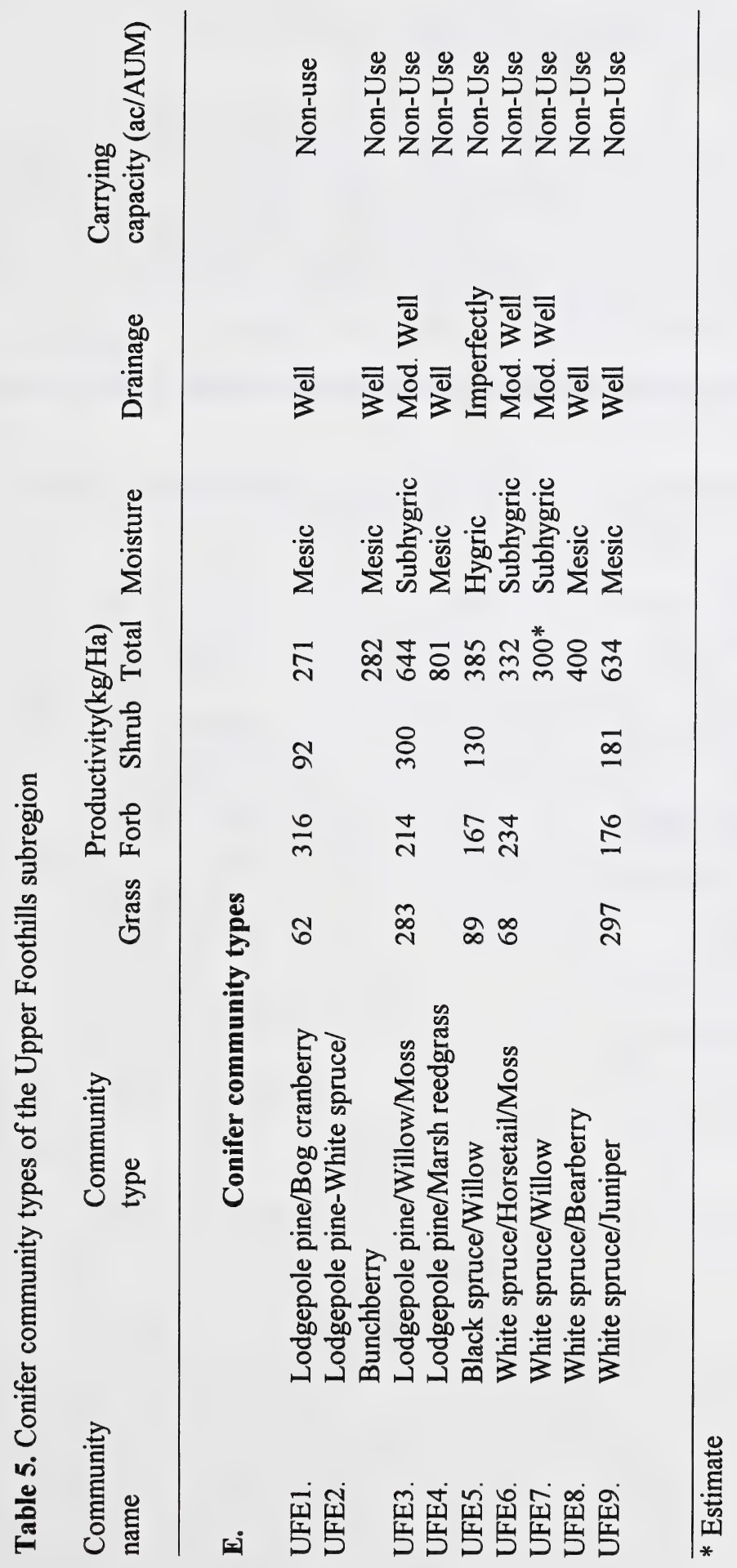





\section{UFE1. Lodgepole pine/Bog cranberry \\ (Pinus contorta/Vaccinium vitis-idaea)}

$\mathbf{n}=6$ This community type is common on dry, coarse textured, well drained sites throughout the Upper Foothills subregion and is part of the subxeric/poor ecosite described by Beckingham et al. (1996). The sites are generally located on slopes with southerly aspects. This community type is very similar to the Lodgepole pine/Hairy wildrye/Bunchberry community type described by Sundquist et al. (1996), in the Lower Foothills subregion and the Lodgepole pine-White spruce/Low bush cranberry/Twinflower type described by Beckingham (1994) in the same Upper Foothills subregion, but this community type appears to be drier with a poorer nutrient regime. Beckingham (1994), felt that white spruce would eventually dominate the canopy of this community type.

Generally, this community type is not useful for domestic livestock grazing because it does not produce good quality forage.

\section{Plant COMPOSITION Canopy Cover(\%)}

TREES

LODGEPOLE PINE

(Pinus contorta)

WHITE SPRUCE

(Picea glauca)

4

SHRUBS

BOG CRANBERRY

(Vaccinium vitis-idaea)

25

LABRADOR TEA

(Ledum groenlandicum)

FORBS

BUNCHBERRY
(Cornus canadensis)

TWINFLOWER

(Linnaea borealis)

RUNNING RASPBERRY

(Rubus pubescens)

BEARBERRY

(Arctostaphylos uva-ursi)

\section{ENVIRONMENTAL VARIABLES}

MOISTURE REGIME (MEAN):

SUBXERIC-SUBMESIC

NUTRIENT REGIME (MEAN

SUBMESOTROPHIC (2.8)

ELEVATION:

$1400-1475(1442) \mathrm{M}$

SOIL DRAINAGE (MEAN):

WELL

\section{CARRYING CAPACITY}

FORAGE PRODUCTION IN KG/HA (+-STD. DEV.)

GRASS 62

FORBS 316

SHRUB 92

TOTAL 271(144)

RECOMMENDED STOCKING RATE NON-USE

GRASSES

HAIRY WLDRYE

(Elymus innovatus)

Moss 



\section{UFE2. Lodgepole pine-White spruce/Bunchberry (Pinus contorta-Picea glauca/Cornus canadensis)}

$\mathbf{n}=4$ This community type represents the modal type on mesic/mesotrophic sites throughout the Upper Foothills subregion. Strong (1992), found that lodgepole pine dominated the reference sites in this subregion with white spruce succession occurring on undisturbed areas. Beckingham (1994) described a similar community type (Pl-Sw/Low bush cranberry/Twinflower) and felt that white spruce and balsam fir will eventually dominate the canopy. The change in canopy dominance will lead to a decline in understory cover of shrubs and forbs. As succession occurs moss cover will increase.

This community type would be rated as non-use range for domestic livestock. There is little forage that would attract livestock use.

\section{Plant Composition Canopy Cover(\%)}

TREES

LODGEPOLE PINE

(Pinus contorta)

WHITE SPRUCE

(Picea glauca)

SHRUBS

DWARF BLBERRY OR BLUEBERRY

(Vaccinium caespitosum)

BOG CRANBERRY

(Vaccinium vitis-idaea)

WILLOW SPP.

(Salix spp.)

FORBS

WIID STRAWBERRY

(Fragaria virginiana)

BUNCHBERRY

(Cornus canadensis)

TWIN-FLOWER

(Linnaea borealis)

GRASSES

HAIRY WIID RYE

(Elymus innovatus)

MARSH REEDGRASS

(Calamagrostis canadensis)

Moss
16

\section{ENVIRONMENTAL VARIABLES}

MOISTURE REGIME (MEAN): MESIC (5)

NUTRIENT REGIME (MEAN): MESOTROPHIC (3)

ELEVATION:

$1330-1500(1410) \mathrm{M}$

SoIL DRAINAGE (MEAN):

WELL

\section{CARRYING CAPACITY}

FORAGE PRODUCTION IN KG/HA (+-STD. DEV.)

TOTAL $282(186)$

\section{Suggested StOckING RATE NON-USE}





\section{UFE3. Lodgepole pine/Willow/Moss \\ (Pinus contorta/Salix spp.Moss spp.)}

$\mathbf{n}=\mathbf{3}$ This community type is very similar to the other lodgepole pine dominated community types, but is found on wetter soils that lack development. This community type is slightly drier than the Pl-Sb/Labrador teaWhortleberry/Bunchberry/Feathermoss type described by Beckingham (1994) and the Black spruce/Willow dominated community type described in this guide. Herbaceous plants are scarce in the understory of this community type. As a result, there is little forage for domestic livestock and this community would be rated non-use.

\section{Plant Composition Canopy Cover(\%)}

TREES

\section{LODGEPOLE PINE}

(Pinus contorta)

WHITE SPRUCE

(Picea glauca)

SHRUBS

WIILOW SPP.

(Salix spp.)

FORBS

BUNCHBERRY

(Cornus canadensis)

WIID STRAWBERRY

(Fragaria virginiana)

TWIN-FLOWER

(Linnaea borealis)

PALMATE LEAVED COLTSFOOT

(Petasites palmatus)

GRASSES

HAIRY WIID RYE

(Elymus innovatus)

MARSH REEDGRASS

(Calamagrostis canadensis)

Moss

32

13

\section{ENVIRONMENTAL VARIABLES}

MOISTURE REGIME (MEAN):

SUBHYGRIC (5.70)

NUTRIENT REGIME (MEAN):

PERMESOTROPHIC (3.70)

ElEvation:

$1390-1430(1405) \mathrm{M}$

\section{CARRYING CAPACITY}

Forage Production IN KG/HA (+-STD. DEV.) GRASS 283

FORBS 214

SHRUBS 300

TOTAL 644
SUGgested StOCKING RATE NON-USE 



\section{UFE4. Lodgepole pine/Marsh reedgrass (Pinus contorta/Calamagrostis canadensis)}

n=3 This community type is similar to the Lodgepole pine/Hairy wildrye/Fireweed-Peavine community type described by Sundquist et al. (1996). The tree canopy is open which allows good understory growth.

The good understory forage production and easy access through this community type makes this type useful for livestock grazing. If this community type occurs adjacent to a physical feature that attracts livestock to the area, it may be considered primary range.

\section{Plant CoMposition Canopy Cover(\%)}

TREES

LODGEPOLE PINE

(Pinus contorta)

WHITE SPRUCE

(Picea glauca)

SHRUBS

PRICKLY ROSE

(Rosa acicularis)

BOG CRANBERRY

(Vaccinium vitis-idaea)

FORBS

BUNCHBERRY

(Cornus canadensis)

FIREWEED

(Epilobium angustifolium)

TWIN-FLOWER

(Linnaea borealis)

LINDLEY'S ASTER

(Aster ciliolatus )

GRASSES

HAIRY WIID RYE

(Elymus innovatus)

MARSH REEDGRASS

(Calamagrostis canadensis)
22

12

1

2

5

3

4

3

5

12

12

\section{ENVIRONMENTAL VARIABLES}

MOISTURE REGIME (MEAN): $\operatorname{MESIC}(5.00)$

NUTRIENT REGIME (MEAN): MESOTROPHIC (3.0)

Elevation:

1350-1380(1365) M

SOIL DRAINAGE (MEAN):

WELL

\section{CARRYING CAPACITY}

FORAGE PRODUCTION IN KG/HA (+-STD. DEV.)

TOTAL $801(346)$

\section{SUGgEsted STOCKING RATE} NON-USE

Moss 



\section{UFE5. Black spruce/Willow \\ (Picea mariana/Salix spp.)}

$\mathbf{n}=\mathbf{2}$ This community type is characterized by a dominant cover of black spruce and a sparse understory cover. The sites are moist in the spring and dry out later in the growing season. Corns and Annas (1986), found that these forests have fire origin and can persist for more than 150 years.

This community type would be considered non-use for domestic livestock.

\section{Plant COMPOSITION CANopy Cover(\%)}

TREES

BLACK SPRUCE

(Picea mariana)

WHITE SPRUCE

(Picea glauca)

SHRUBS

WILLOW SPP.

(Salix spp.)

LABRADOR TEA

(Ledum groenlandicum)

FORBS

PALMATE LEAVED COLTSFOOT

(Petasites palmatus)

BUNCHBERRY

(Cornus canadensis)

WILD STRAWBERRY

(Fragaria virginiana)

WOODLAND HORSETAII

(Equisetum sylvaticum)

GRASSES

WATER SEDGE

(Carex aquatilis)

GRACEFUL SEDGE

(Carex praegracilis)

Moss
15

6

7

6

7

1

5

4

51

\section{ENVIRONMENTAL VARIABLES}

MOISTURE REGIME (MEAN):

HYGRIC (6.5)

NUTRIENT REGIME (MEAN):

PERMESOTROPHIC (4)

Elevation:

$1415-1454(1435) \mathrm{M}$

SOIL DRAINAGE (MEAN):

IMPERFECTLY

\section{CARRYING CAPACITY}

FORAGE PRODUCTION IN KG/HA (+-STD. DEV.)

GRASS $89(38)$

FORBS 167(212)

SHRUBS 130(141)

TOTAL 385(316)

\section{Suggested Stocking RATE}

NON-USE 


\section{UFE6. White spruce/Horsetail/Moss \\ (Picea glauca/Equisetum arvense/Moss spp.)}

$\mathbf{n}=1 \quad$ This community type is successionally more advanced than the Lodgepole pine-White spruce/Bunchberry community type previously described. The lack of fire disturbance has allowed white spruce to succeed into the lodgepole pine canopy and dominate the site. As these stands mature the canopy becomes more closed, shading the understory vegetation and allowing moss cover to increase. The sparseness and low palatablity of the vegetation limits the use of these stands by domestic livestock.

\section{Plant COMPOSITION CANopy Cover(\%)}

TREES

WHTE SPRUCE

(Picea glauca)

BALSAM POPLAR

(Populus balsamifera)

SHRUBS

LOW BUSH CRANBERRY

(Viburnum edule)

FORBS

PALMATE LEAVED COLTSFOOT

(Petasites palmatus)

SCOURING RUSH

(Equisetum scirpoides)

TWINFLOWER

(Linnaea borealis)

HORSETAII

(Equisetum arvense)

TALL LUNGWORT OR BLUEBELLS

(Mertensia paniculata)

GRASSES

HAIRY WILDRYE

(Elymus innovatus

Moss

16

10

9

3

3

91

\section{ENVIRONMENTAL VARIABLES}

MOISTURE REGIME (MEAN):

SUBHYGRIC-HYGRIC

NUTRIENT REGIME (MEAN):

PERMESOTROPHIC (3.50)

Elevation:

$1030-1158(1101) \mathrm{M}$

SOIL DRAINAGE (MEAN):

MODERATELY WELL

\section{CARRYING CAPACITY}

FORAGE PRODUCTION IN KG/HA (+-STD. DEV.)

GRASS 68

FORBS 234

TOTAL 332

\section{Suggested STOCKING RATE} NON-UsE 


\section{UFE7. White spruce/Willow \\ (Picea glauca/Salix spp.)}

$\mathbf{n = 1}$ This community type is similar to the White spruce/Bunchberry/Moss community type, but is found on wetter

sites, with poorer drainage. The wetter sites favour the growth of willow in the understory. The high cover of willow and spruce limits the amount of light reaching the understory. Consequently, there is little forage for domestic livestock.

\section{Plant COMposition Canopy Cover(\%)}

TREES

WHITE SPRUCE

(Picea glauca)

LODGEPOLE PINE

SHRUBS

(Pinus contorta)

(Salix spp.)

BOG BIRCH

(Betula glandulosa)

LOW BLBERRY OR BLUEBERRY

(Vaccinium caespitosum)

\section{FORBS}

CREAM COLORED VETCHLING

(Lathyrus ochroleucus)

LINDLEY'S ASTER

(Aster ciliolatus)

WILD STRAWBERRY

(Fragaria virginiana)

ALPINE ASTER

(Aster alpinus)

YARROW

(Achillea millefolium)

FIREWEED

(Epilobium angustifolium)

TWIN-FLOWER

(Linnaea borealis)

GRASSES

GRACEFUL SEDGE

(Carex praegracilis)

HAIRY WILD RYE

(Elymus innovatus)

\section{ENVIRONMENTAL VARIABLES}

MOISTURE REGIME (MEAN):

SUBHYGRIC

NUTRIENT REGIME (MEAN):

PERMESOTROPHIC

ELEVATION:

$1646 \mathrm{M}$

SOIL DRAINAGE (MEAN):

MODERATELY WELL

\section{CARRYING CAPACITY}

Forage PRODUCTION IN KG/HA (+-STD. DEV.)

$$
\text { Total 300* *Estimate }
$$

\section{SUgGested StOcKnng RATE NON-USE}





\section{UFE8. White spruce/Bearberry \\ (Picea glauca/Arctostaphylos uva-ursi)}

$\mathbf{n = 1}$ This community type is similar to the White spruce/Buffaloberry/Bearberry c.t. described by Sundquist et al. (1996) in Lower Foothills. They found this type to be fairly dry type, with a poor nutrient regime; as indicated by the high abundance of bearberry. It may also be somewhat windswept and dessicated; as indicated by the low tree canopy cover.

If this community type is located near a physical feature that attracts livestock to the area it may be considered to be primary or secondary range. In other instances though, where it is not near an attractive feature, this community type would be considered non-use.

\section{Plant Composition Canopy Cover(\%)}

TREES

WHTE SPRUCE

(Picea glauca)

ASPEN

(Populus tremuloides)

SHRUBS

SHRUBBY CINQUEFOI

(Potentilla fruticosa)

WILLOW SPP.

(Salix spp.)

BOG BIRCH

FORBS

(Betula glandulosa)

\section{BEARBERRY}

(Arctostaphylos uva-ursi)

SHOWY LOCOWEED

(Oxytropis splendens)

WILD STRAWBERRY

(Fragaria virginiana)

ALPINE MIIKVETCH

(Astragalus alpinus)

ClOVER

(Trifolium repens)

DANDELION

GRASSES

(Taraxacum officinale)

PURPLE OATGRASS

(Schizachne purpurascens)

SLENDER WHEATGRASS

(Agropyron trachycaulum)

BLUNT SEDGE

(Carex obtustata)
23

18

10

\section{ENVIRONMENTAL VARIABLES}

MOISTURE REGIME (MEAN): SUBXERIC

8

NUTRIENT REGIME (MEAN):

SUBMESOTROPHIC

ELEVATION:

12

$1311 \mathrm{M}$

SOIL DRAINAGE (MEAN):

WELL

7

10

19

7

6

6
SUGgested STOCKING RATE NON-USE

\section{CARRYING CAPACITY}

FORAGE PRODUCTION IN KG/HA (+-STD. DEV.)

TOTAL $\quad 400$

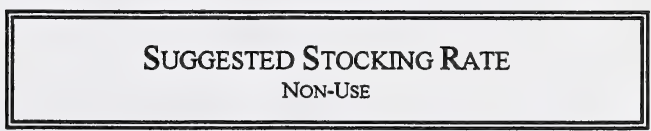




\section{UFE9. White spruce/Juniper \\ (Picea glauca/Juniperus horizontalis)}

$\mathbf{n}=2$ This community type was described along the north shore of Brule lake. It is characteristic of the finetextured, calcareous loess deposits, which have blown down the Athabasca river valley from Jasper National Park. The soils of this community have a high $\mathrm{pH}(8)$, which supports a good cover of hairy wildrye. This community type is extremely slow growing. When harvested the cutblocks resemble native grasslands (Juniper/Hairy wildrye (UFF1) and Rose/Hairy wildrye (UFF2)).

\section{PLANT COMPOSITION CANOPY COVER(\%)}

TREES

WHITE SPRUCE

(Picea glauca)

50

SHRUBS

SHRUBBY CINQUEFOIL

(Potentilla fruticosa)

CREEPING JUNIPER.

(Juniperus horizontalis)

PRICKI Y ROSE

FORBS

(Rosa acicularis)

WHITE CAMAS

(Zigadenus elegans)

SHOWY LOCOWEED

(Oxytropis splendens)

NORTHERN HEDYSARUM

(Hedysarum boreale)

NORTHERN BEDSTRAW

(Galium boreale)

BASTARD TOAD FLAX

(Comandra umbellata)

GRASSES

HAIRY WILDRYE

(Elymus innovatus)

BLUNT SEDGE

(Carex obtustata)

44

7

2

2

2

2

14

5

\section{ENVIRONMENTAL VARIABLES}

MOISTURE REGIME (MEAN):

SUBMESIC-MESIC

NUTRIENT REGIME (MEAN):

SUBMESOTROPHIC

ELEVATION:

$1066 \mathrm{M}$

SLOPE: $5 \%$

ASPECT: SOUTHERLY

SoIl DRAINAge (MEAN):

WELL

\section{CARRYING CAPACITY}

FORAGE PRODUCTION IN KG/HA (+-STD. DEV.)

GRASS 297(294-300)

FORB 176(146-206

SHRUB 181(36-326)

TOTAL 654(536-772)
Suggested STOCKING RATE NON-USE 



\section{Cutblock community types}

Harvesting occurs throughout the Upper Foothills subregion. In general cutblocks provide only a limited source of forage for domestic livestock in this subregion. The Brule stock association is an example where the livestock rely principally on the forage within harvested cutblocks. Cutblocks can be an important source of forage for domestic livestock. On average they produce twice as much forage as deciduous stands and nearly 3 times the forage as conifer stands. In the Brule stock association forage production on the cutblocks averaged 3-5 times greater than the unharvested white spruce dominated forest.

The only two cutblock community types described in this guide were described from the Brule stock association. These included the Juniper/Hairy wildrye and Rose/Hairy wildrye community types. Both these types have very little growth of regenerating trees and resemble native grasslands (Figure 7). The Juniper/Hairy wildrye community type is successionally more advanced than the Rose/Hairy wildrye community type. As a result the production of the Juniper/Hairy wildrye community type is $900 \mathrm{~kg} / \mathrm{ha}$ greater.

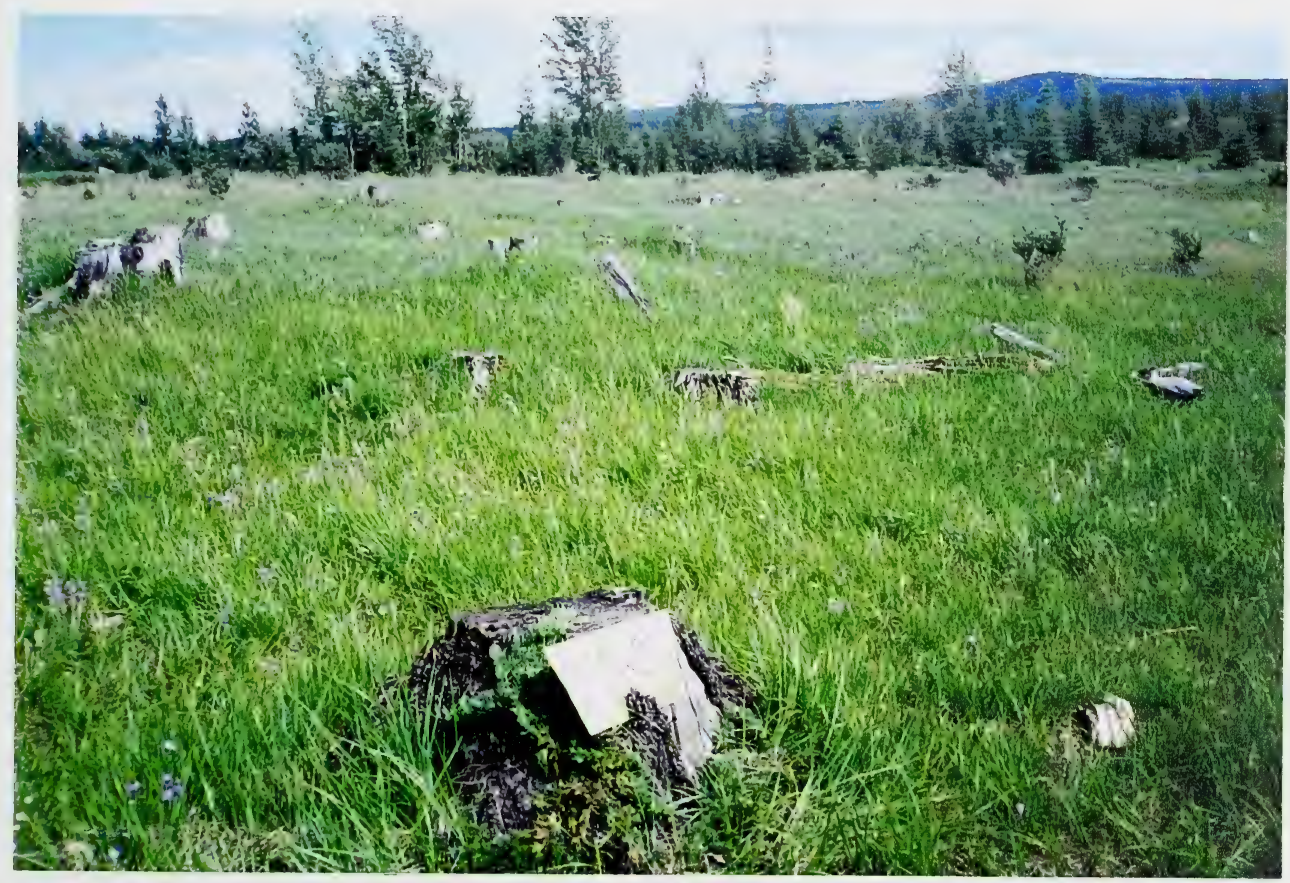

Figure 7. The Juniper/Hairy wildrye community type results from the harvesting of a White spruce/Juniper community. 


\section{UFF1. Juniper/Hairy wildrye \\ (Juniperus horizontalis/Hairy wildrye)}

$\mathbf{n}=4$ This community represents a harvested White spruce/Juniper community along the north shore of Brule lake It is characteristic of the fine-textured, calcareous loess deposits, which have blown down the Athabasca river valley from Jasper National Park. The soils of this community have a high $\mathrm{pH}(8)$, which supports a good cover of hairy wildrye. This community type is extremely slow growing. When harvested the cutblocks resemble native grasslands This community is very similar to the Rose/Hairy wildrye community, but appears to be in a later successional stage This community type was described in older cutblocks (35 yrs) than the Rose/Hairy wildrye community type. As succession occurs on these cutblocks it appears that juniper and grass cover increase causing a corresponding increase in forage production.

\section{Plant COMPOSITION CANOPY COVER(\%)}

UNDERSTORY TREES

WHITE SPRUCE

(Picea glauca)

BALSAM POPLAR

(Populus balsamifera)

ASPEN

(Populus tremuloides)

SHRUBS

SHRUBBY CINQUEFOIL

(Potentilla fruticosa)

CREEPING JUNIPER.

(Juniperus horizontalis)

PRICKLY ROSE

(Rosa acicularis)

WILLOW SPP.

(Salix spp.)

FORBS

WHITE CAMAS

(Zigadenus elegans)

SHOWY LOCOWEED

(Oxytropis splendens)

NORTHERN HEDYSARUM

(Hedysarum boreale)

NORTHERN BEDSTRAW

(Galium boreale)

BEARBERRY

(Arctostaphylos uva-ursi)

GRASSES

HAIRY WILDRYE

(Elymus innovatus)

BLUNT SEDGE
12

8

6

5

(Carex obtustata)

SLENDER WHEATGRASS

(Agropyron trachycaulum)

2

\section{ENVIRONMENTAL VARIABLES}

MOISTURE REGIME (MEAN):

SUBMESIC-MESIC

NUTRIENT REGIME (MEAN):

SUBMESOTROPHIC

ELEVATION:

1051(1036-1066) M

SLOPE:4(3-5)\%

ASPECT: SOUTHERLY

SOIL DRAINAGE (MEAN):

WELL

\section{CARRYING CAPACITY}

FORAGE PRODUCTION IN KG/HA (+-STD. DEV.)

GRASS 603(274-866)

FORB 888(236-1538)

SHRUB 289(12-450)

TOTAL 2587(1614-3732)

SUGgested STOCKING RATE

0.4 HAAUM 0.9 AC/AUM 


\section{UFF2. Rose/Hairy wildrye \\ (Rosa acicularis/Elymus innovatus)}

$\mathbf{n = 1 0}$ This community type represents a White spruce/Juniper community that was harvested 20 years ago. It is very similar to the previously described Juniper/Hairy wildrye community, but lacks the cover of juniper. It appears that harvesting disturbance causes juniper to decline in cover. As succession occurs juniper and density of grass increases, causing forage productivity to increase. The site conditions are so harsh it appears that grass cover has to undergo succession onto the site.

\section{PLANT COMPOSITION CANOPY COVER(\%)}

UNDERSTORY TREES

WHTE SPRUCE

(Picea glauca)

BALSAM POPLAR

(Populus balsamifera)

ASPEN

(Populus tremuloides)

SHRUBS

SHRUBBY CINQUEFOIL

(Potentilla fruticosa)

CREEPING JUNIPER.

(Juniperus horizontalis)

PRICKLY ROSE

(Rosa acicularis)

WILLOW SPP.

(Salix spp.)

FORBS

WHITE CAMAS

(Zigadenus elegans)

SHOWY LOCOWEED

(Oxytropis splendens)

NORTHERN HEDYSARUM

(Hedysarum boreale)

NORTHERN BEDSTRAW

(Galium boreale)

BEARBERRY

(Arctostaphylos uva-ursi)

DANDELION

(Taraxacum officinale)

GRASSES

HAIRY WILDRYE

(Elymus innovatus)

BLUNT SEDGE
11

8

2

1

2

4

6

2

1

4

1

3

24

1

2
(Carex obtustata)

SLENDER WHEATGRASS

(Agropyron trachycaulum)

4

\section{ENVIRONMENTAL VARIABLES}

MOISTURE REGIME (MEAN):

SUBMESIC-MESIC

NUTRIENT REGIME (MEAN):

SUBMESOTROPHIC

ELEVATION:

1081(1036-1279) M

SLOPE: $4(0-20) \%$

ASPECT: SOUTHERLY

SoIl DRAINAGE (MEAN):

WELL

CARRYING CAPACITY

ForAGE PRODUCTION IN KG/HA (+-STD. DEV.)

GRASS 920(400-1600)

FORB 592(250-1370)

SHRUB 122(2-440)

TOTAL 1634(1202-2494)

\section{SUGgested StOCKING RATE}

$0.6 \mathrm{HA}$ AUM $1.3 \mathrm{AC} / \mathrm{AUM}$ 


\section{Literature cited}

Bailey, A.W., M.G. Willoughby, R. Johansen and S. Smith. Management of Yukon Rangelands. Renewable Resources, Yukon Territorial Government, Whitehorse, Yukon. 55pp. ISBN-1-55018-138-6.

Bork, E. 1990. Clearwater allotment: Prescribed burn vegetation survey, evaluation, and discussion. Range Management Section, Alberta Forest Service, Edmonton, Alta. 29pp.

Bork, E. 1994. Ecological classification and management of native ranges in Willmore Wilderness Park. Alberta Environmental Protection. Forest Management Division. Edmonton, Alta. Pub. no. T/282. 65pp.

Beckingham, J. 1994. Field guide to the ecosystems of Northern Alberta. Environmental Protection, Land and Forest Services, Edmonton, Alta. 352pp.

Beckingham, J.D., I.G.W. Corns and J.H. Archibald. 1996. Field guide to ecosites of West-Central Alberta. Nat. Resour. Can., Can. For. Serv., Northwest Reg., North. For. Cent., Edmonton, Alberta. Spec. Rep. 9.

Corns, I.G.W. and P.L. Achuff. 1982. Vegetation type descriptions. In Holland, W.D. and G.M. Coen. Ecological (Biophysical) Land Classification of Banff and Jasper National Parks. Vol II. Soil and Vegetation Resources. Environment Canada and Alberta Institute of Pedology, University of Alberta. Pub. no. SS-82-44. 540pp.

Corns, I.G.W. and R.M. Annas. 1986. Field guide to forest ecosystems of West-Central Alberta. Northern Forestry Center, Canadian Forestry Service, Edmonton, Alta. 251pp.

Daubenmire, R. 1952. Forest vegetation of Northern Idaho and adjacent Washington and its bearing on concepts of vegetation classification. Ecol. Mongr. 22: 301-330.

Daubenmire, R. 1978. Plant Geography. Academic Press. New York. 338pp.

Dept. of Environmental Protection. 1994. Natural regions of Alberta. Alberta Environmental Protection. Edmonton, Alta. Pub. no. I/531. 18pp.

Gauch, H.G. 1982. Multivariate analysis in community ecology. Cambridge University Press, Cambridge, 298pp.

Mackinnon, A., J. Pojar, and R. Coupe. 1992. Plants of Northern British Columbia. Lone Pine Publishing, Edmonton, Alta. 345pp.

Mueggler, W.F. 1988. Aspen community types of the Intermountain Region. U.S.D.A. 

Intermoutain Research Station. INT-250. 133pp.

Rangeland Resource Information System. 1991. Outline and guide, a proposal. Range Management Section, Alberta Forest Service, Edmonton, Alta. 19pp.

Range Survey Manual. 1992. Range Management Section, Alberta Forest Service. Edmonton, Alta. 39pp.

Strong, W.L. and H.G. Anderson. 1980. Ecological land classification and evaluation reference manual. Resource Evaluation reference manual. Resource Evaluation Branch, Energy and Natural Resources. Edmonton, Alta. 160pp.

Strong, W.L. and K.R. Leggat. 1992. Ecoregions of Alberta. Alberta Forestry, Lands and Wildlife, Resource Information Branch, Edmonton, Alta. T/245. 77pp.

Strong, W.L. 1992. Ecoregions and Ecodistricts of Alberta. Alberta Forestry, Lands and Wildlife. Edmonton, Alta. Pub. no. T/244. 77pp.

Sundquist, K., B. Olson, M.A. Alexander, M.G. Willoughby and D. Smith. 1994. Range plant community types and carrying capacity of the Lower Foothills subregion of Alberta. Range Managment Section, Forest Management Division, Edmonton, Alta. 100pp.

Willoughby, M.G. 1992. Rangeland Reference Areas, Plant communities, ecology and response to grazing in Division 3. Forestry, Lands and Wildlife, Alberta Forest Service, Edmonton, Alta. T/269, 36pp.

Willoughby, M.G. and D. Smith. 1996. Range plant community types and carrying capacity for the Subalpine and Alpine subregions of Alberta. Environmental Protection. Land and Forest Services. Edmonton, Alta. 80pp.

Youngblood, A. Community type classification of forest vegetation in young, mixed stands, Interior Alaska. U.S.D.A. Forest Service, Pacific Northwest Research Station. PNW-RP458. 42pp. 



\section{APPENDIX 1: VEGETATION SPECIES LISTS FOR EACH PLANT COMMUNITY TYPE IN THE UPPER FOOTHILLS SUBREGION}

(REFER TO VOLUME II) 


